\title{
Thermochemical Equilibrium Model of Synthetic Natural Gas Production from Coal Gasification Using Aspen Plus
}

\author{
Rolando Barrera, ${ }^{1}$ Carlos Salazar, ${ }^{2}$ and Juan F. Pérez ${ }^{3}$ \\ ${ }^{1}$ Grupo CERES, Departamento de Ingeniería Química, Facultad de Ingeniería, Universidad de Antioquia (UdeA), \\ Calle 70 No. 52-21, Medellín, Colombia \\ ${ }^{2}$ Celsia S.A. ESP, Sede zona Franca Celsia, vía 40 No. 85-555, Barranquilla, Colombia \\ ${ }^{3}$ Grupo de Manejo Eficiente de la Energía (Gimel), Departamento de Ingeniería Mecánica, Facultad de Ingeniería, \\ Universidad de Antioquia (UdeA), Calle 70 No. 52-21, Medellín, Colombia \\ Correspondence should be addressed to Juan F. Pérez; juanpb@udea.edu.co
}

Received 30 April 2014; Accepted 15 July 2014; Published 13 August 2014

Academic Editor: Alírio Rodrigues

Copyright (C) 2014 Rolando Barrera et al. This is an open access article distributed under the Creative Commons Attribution License, which permits unrestricted use, distribution, and reproduction in any medium, provided the original work is properly cited.

\begin{abstract}
The production of synthetic or substitute natural gas (SNG) from coal is a process of interest in Colombia where the reserves-toproduction ratio $(\mathrm{R} / \mathrm{P})$ for natural gas is expected to be between 7 and 10 years, while the $\mathrm{R} / \mathrm{P}$ for coal is forecasted to be around 90 years. In this work, the process to produce SNG by means of coal-entrained flow gasifiers is modeled under thermochemical equilibrium with the Gibbs free energy approach. The model was developed using a complete and comprehensive Aspen Plus model. Two typical technologies used in entrained flow gasifiers such as coal dry and coal slurry are modeled and simulated. Emphasis is put on interactions between the fuel feeding technology and selected energy output parameters of coal-SNG process, that is, energy efficiencies, power, and SNG quality. It was found that coal rank does not significantly affect energy indicators such as cold gas, process, and global efficiencies. However, feeding technology clearly has an effect on the process due to the gasifying agent. Simulations results are compared against available technical data with good accuracy. Thus, the proposed model is considered as a versatile and useful computational tool to study and optimize the coal to SNG process.
\end{abstract}

\section{Introduction}

Coal is a major source of energy, accounting for $\sim 25 \%$ of the world energy supplies and $\sim 40 \%$ of the world electricity generation. It is predicted that coal will continue to play an important role in meeting the world's increasing energy demands in the foreseeable future [1]. However, the use of coal faces several challenges such as clean and efficient energy systems, the challenge of carbon storage and sequestration, and the environmental impacts due to the mining $[1,2]$. The coal gasification in entrained flow reactors with steam and/or oxygen produces synthesis gas (syngas), which is a mixture of mostly hydrogen and carbon monoxide [3]. Therefore, the urgent needs to produce fuels and chemical products from syngas prompt the study of this thermochemical process $[3,4]$. Gasification units in electric power plants produce a fuel gas to drive gas turbines. And gasification in chemical plants yields syngas that can be used to produce a wide spectrum of chemical products, such as ammonia, methanol, methane, and liquid fuels [5]. Future plants will be hybrid power/chemical plants with gasification as the key unit operation; as a consequence, the thermochemical process has been emerging as the premier unit operation in the energy and chemical industries. Therefore, the gasification continues to be an important topic to research $[3,6,7]$.

The production of SNG from coal is a process of particular interest to Colombia, where depletion of natural gas is being foreseen in the coming years due to the increasingly high level of demand of the last several years [8]; carbon reserves are still foreseen to last for around 90 years $[9$, 10]. These reserves are the highest coal reserves in South America. The coal production in Colombia is distributed by 
regions as follows: $50.92 \%$ Cesar, the main coal mines are $E l$ Descanso, Calenturitas, La Loma, and Jagua; 38.87\% La Guajira (Cerrejón coal mine); 3.57\% Cundinamarca (Guaduas coal mine); 3.21\% Boyacá (Tunja-Duitama, Sogamoso-Jericó, and Chinavita-Umbita-Tinabá coal mines); $2.22 \%$ Norte de Santander (Zulia, Cúcuta, Tasajero, and Toledo coal mines); and $1.21 \%$ others. Therefore, one of the main challenges facing the country is finding how to add value to mineral resources under environmental, efficiency, and sustainability criteria [1]. Therefore, this study is focused on modeling the SNG production process by means of coal gasification in entrained flow as a promising and clean alternative way to produce energy and fuels.

Several studies of modeling coal gasification have been published in the specialized literature. Gräbner and Meyer [11] analyzed the gasification process under the first and second thermodynamic laws. The aim has been to study the coal rank effect (standard and high ash content coals) on the gasifier technology (Shell, Siemens, Texaco, ConocoPhillips, and High Temperature Winkler-HTW). The higher exergy efficiencies were reached by slurry feeding and dry feeding technologies with the standard coal.

Kunze and Spliethoff [12] developed a model with Aspen Plus to simulate a generic entrained flow gasifier. The objective was to analyze the effect of the fuel feed system, that is, dry feed and slurry feed on the gasification process at 30 bar. They found higher energy efficiency for dry feed gasification (83\%) when compared with slurry feed (72\%). Seifkar et al. [13] studied the effect of coal supply and reactor cooling system on the entrained flow gasifier process. They analyzed three systems: the first one included dry coal feed and reactor cooling with water, the second consisted of one dry coal feed with partial cooling with water, and the last one was a coal slurry feed supply system without refrigeration. The authors discussed advantages and disadvantages associated with the studied systems.

Maurstad et al. [14] presented a model with Aspen Plus to characterize an integrated gasification combined cycle plant (IGCC) with and without $\mathrm{CO}_{2}$ capture. They carried out a comparison between two technologies (dry feed and slurry feed) with five types of coal in the IGCC plant energy behavior. They found that the thermal efficiency and power of the IGCC plant diminished with the coal rank for the slurry feed technology, while the dry feed technology was not affected. Yu et al. [15] studied the effect of the gasification technology on the water gas shift reaction unit used for Fischer-Tropsch processes. The study was conducted by means of an Aspen Plus model. They showed that the dry feed technology presented higher energy efficiency and lesser $\mathrm{H}_{2} / \mathrm{CO}$ ratio with regards to the slurry feed technology. Prins et al. [16] studied different ways of carbon capture and sequestration on an IGCC plant by process modeling. The dry feed technology was analyzed because of its higher efficiency in the gasification process $(82.3 \%)$ against the gasifiers with slurry feeding systems (about 75\%).

Bockelie et al. [17] studied the syngas composition and the cold gas efficiency of two commercial gasifiers using a computational fluids dynamic model (CFD). The commercial gasifiers considered were Shell (dry feed technology with one gasification stage) and ConocoPhillips (slurry feed technology with two gasification stages). The authors highlight the agreement between the simulation results with the proposed model and the data reported in the literature. Armin [18] and Silaen and Wang [19] conducted numerical simulations of the gasification process in entrained flow reactors. They studied the effect of the operating parameters such as coal dry feeding and slurry feeding systems, type of gasifying agent, and coal rank in the global gasifier performance. They highlighted that syngas heating value $\left(\mathrm{HHV}_{\text {syngas }}\right)$ is higher with the dry system technology. Moreover, the carbon conversion efficiency and $\mathrm{HHV}_{\text {syngas }}$ increase when oxygen is used as gasifying agent because the nitrogen inert effects of the air are avoided.

Using biomass as a feedstock to produce SNG by means of gasification, Vitasari et al. [20] developed an Aspen Plus model to conduct an exergy analysis of different biomass types (wood, urban solid wastes (USW), and sewage sludge). They simulated the process under different operating conditions, including variations in the reactor pressure as well as temperature and pressure in the methanation reactor. The global process exergy efficiency was reached with wood being between 53 and 58\%; for USW was between 42 and $46 \%$ and for the sewage sludge being from 47 to $57 \%$. Tremel et al. [21] simulated a small scale plant to produce SNG via indirect steam biomass gasification. The thermal biomass input to the gasifier was $500 \mathrm{~kW}$. The model was developed under equilibrium approach using Aspen Plus and considering the minimization of the Gibbs free energy. They studied the effect of four operation conditions on the energy efficiency of the process. The ratio between the energies of SNG and biomass reached values around $66-75 \%$. This indicator increases when the pyrolyzed char is used to feed the steam boiler.

Heyne et al. [22] studied the thermal integration between an existing biomass steam and power cycle (CHP) and the production process of SNG via indirect gasification. The thermal plant was modeled and simulated by means of Aspen Plus, and the analysis was conducted using pinch technology. The process global efficiency reached was about $90 \%$, and it indicates that the SNG production is feasible via indirect gasification coupled to a CHP plant.

On the other hand, the Department of Energy from the United States through the National Energy Technology Laboratory conducted a diagnosis of commercial entrained flow gasifiers. The analysis was carried out by means of Aspen Plus models and validated with data from 14 IGCC plants. The IGCC plants efficiencies without $\mathrm{CO}_{2}$ capture were $42.1 \%$, 39.7\%, and 39\% for Shell, ConocoPhillips, and Texaco, respectively. Regarding the costs, the specific costs of the IGCC plants without $\mathrm{CO}_{2}$ capture were about 2350 $\$ \mathrm{USD} / \mathrm{kW}$ for ConocoPhillips (slurry feed technology) and 2710 \$USD/kW for Shell (dry feed technology) [23].

The coal gasification process has been widely studied under different operational conditions. This has been done by means of modeling and simulation strategies with software tools such as Aspen Plus to analyze the thermochemical process or to study how the input parameters affect the IGCCs process. According to the literature cited, the effect of coal gasification technology on the SNG production using 
Aspen Plus model has not been presented. Therefore, in the current study, two typical technologies used in entrained flow gasifiers with dry coal and slurry coal feed systems are modeled and simulated. Emphasis is put on interactions between the fuel supply technologies and energy output parameters of coal-SNG process, including carbon conversion efficiency, cold gas efficiency, process and global energy efficiencies, SNG heating value, Wobbe Index, and power. Since most of the revised literature did not go deep into model details, this study presents as an additional contribution, a comprehensive and complete model of coal to SNG process under thermochemical equilibrium developed in Aspen Plus.

\section{Methodology}

2.1. Coal-SNG Process Description: Coal Slurry Feed Mode. The complete process to produce SNG via coal gasification in entrained flow reactors with slurry feeding system includes several stages that are shown in Figure 1. Stage 1 includes the solid fuel inlet into the system as a slurry after mixing it with water. The typical concentration of water in the slurry is around $30-40 \%$ wt., which means that a significant portion of heat generated by coal combustion will be used to vaporize water in the gasifier at higher pressure. Therefore, the cold gas efficiency (CGE) of wet feed gasifiers is expected to be lower (between 8 and 10\%) than the dry feed gasifiers [12, 16].

The entrained flow gasifier is modeled with two gasification stages, $70 \%$ of slurry mass flow goes into a pressurized reactor (Stage 2, Figure 1) where the slurry reacts with oxygen (98\% purity). The use of air as an oxidant is avoided due to high flow rates that produce stack gas by the higher amount of nitrogen. The syngas formed in this reactor flows to a second pressurized reactor (Stage 3, Figure 1) where reaction takes place with the remaining $30 \%$ of the initial slurry mass flow. In the second reactor, there is not an addition of oxygen. In this way, the coal devolatilization is promoted and the reduction reactions for $\mathrm{CO}_{2}, \mathrm{H}_{2}$, and $\mathrm{H}_{2} \mathrm{O}$ with char are driving to formation of $\mathrm{H}_{2}, \mathrm{CH}_{4}$, and $\mathrm{CO}$ as majority compounds, (1)-(3). Consider

$$
\begin{gathered}
\mathrm{C}+\mathrm{CO}_{2} \Longleftrightarrow 2 \mathrm{CO} \\
\mathrm{C}+2 \mathrm{H}_{2} \Longleftrightarrow \mathrm{CH}_{4} \\
\mathrm{C}+\mathrm{H}_{2} \mathrm{O} \Longleftrightarrow \mathrm{CO}+\mathrm{H}_{2}
\end{gathered}
$$

The units downstream from the gasifier are mostly standard gas-phase processes [3]. Syngas produced in the gasification process (Stage 2-3, Figure 1) goes through a separator that removes unreacted coal (Stage 4, Figure 1). Unreacted coal is reentered to the process as recycled char in Stage 1. Further, in Stage 5 (Figure 1) the syngas is quenched and cooled with water with the corresponding ash solidification (slag formation). The slag is removed from the syngas in a particulate removal system. According to the particle size distribution, the particulate matter clean-up process can include cyclones, electrostatic precipitators, and bag filters. After cooling and particulate removal, the syngas is fed into a water gas shift reactor (WGSR), where hydrogen formation is promoted (Stage 6, Figure 1). By adding steam to the WGSR, carbon monoxide and water react to carbon dioxide and hydrogen (see (4)). In this way, the WGSR can produce a modified syngas with specific molar ratio $\mathrm{H}_{2} / \mathrm{CO}$ by adjusting any of the reactor inlet flows (steam and/or syngas). Consider

$$
\mathrm{CO}+\mathrm{H}_{2} \mathrm{O} \Longleftrightarrow \mathrm{CO}_{2}+\mathrm{H}_{2}
$$

The molar ratio $\mathrm{H}_{2} / \mathrm{CO}$ at the exit of the WGSR will depend on aims of the entire plant process; that is, for dimethyl synthesis, a molar ratio $\mathrm{H}_{2} / \mathrm{CO}=1$ is desired, while Fischer-Tropsch process requires a ratio $\mathrm{H}_{2} / \mathrm{CO}=2$. For SNG production, a molar relation $\mathrm{H}_{2} / \mathrm{CO}=3$ is preferred $[21,24,25]$. Thereby, a portion of the syngas from Stage 5 (Figure 1) is bypassed and only between $60 \%$ and $70 \%$ of the syngas mass flow goes through the WGSR. In chemical applications, the synthesis gas and/or hydrogen is fed to downstream chemical plants. The carbon dioxide is suitable for sequestration [3], or it can be also used as a carrier gas in entrained flow gasifiers with dry feeding technologies [12]. In the SNG production scheme (Figure 1), the syngas with adjusted-molar ratio $\mathrm{H}_{2} / \mathrm{CO}$ is then passed through an acid gases recovery unit (AGR), which consists of a separation unit that removes acid gases (Stage 7, Figure 1). In the AGR unit the syngas is cleaned up from acid gases and other impurities that are formed upstream in the process, such as $\mathrm{NH}_{3}, \mathrm{HCl}, \mathrm{H}_{2} \mathrm{~S}, \mathrm{COS}, \mathrm{H}_{2} \mathrm{O}$, and $\mathrm{CO}_{2}$, among others. This cleaning process is necessary because the next process stage (Stage 8, Figure 1) consists of a catalytic reactor whose performance highly depends on the quality of the reactor inlet gases [24]. Furthermore, in the reducing environment present in gasifiers, the sulfur and nitrogen impurities appear as hydrogen sulfide and ammonia, respectively. Both of these chemicals can be easily removed using pollutant removal systems (i.e., sulfur dioxide absorbers and $\mathrm{NOx}$ reactors) and are potentially valuable by-products to be used as well or as raw material for different chemical process, that is, a sulfuric acid plant production. In the current process, the outcoming gas from Stage 7 (Figure 1) is constituted mainly by $\mathrm{H}_{2}$ and $\mathrm{CO}$. This syngas with adjusted-molar ratio $\mathrm{H}_{2} / \mathrm{CO}=3$ flows to the methanation stage (Stage 8, Figure 1) where methane formation is promoted (see (5)). Even when additional reactions could occur in the methanation reactor, that is, (6), the methane formation by (5) is thermodynamically favored due the operating conditions in the reactor (temperature and pressure) as well as the composition of the reactor inlet gases and the adapted catalytic technology. Simulations in this study revealed that, under the conditions given, the equilibrium constant of the reaction presented in (6) is 22 times lower than equilibrium constant of the reaction presented in (5). Thus, there are no significant errors in assuming (5) as the only reaction taking place on the methanation reactor.

Stage 9 (Figure 1) corresponds to the SNG conditioning stage. The SNG is cooled; therefore, steam formed in Stage 8 (see (5)) is condensed and separated from the SNG. The outlet of this block (Stage 10, Figure 1) corresponds to the desired 


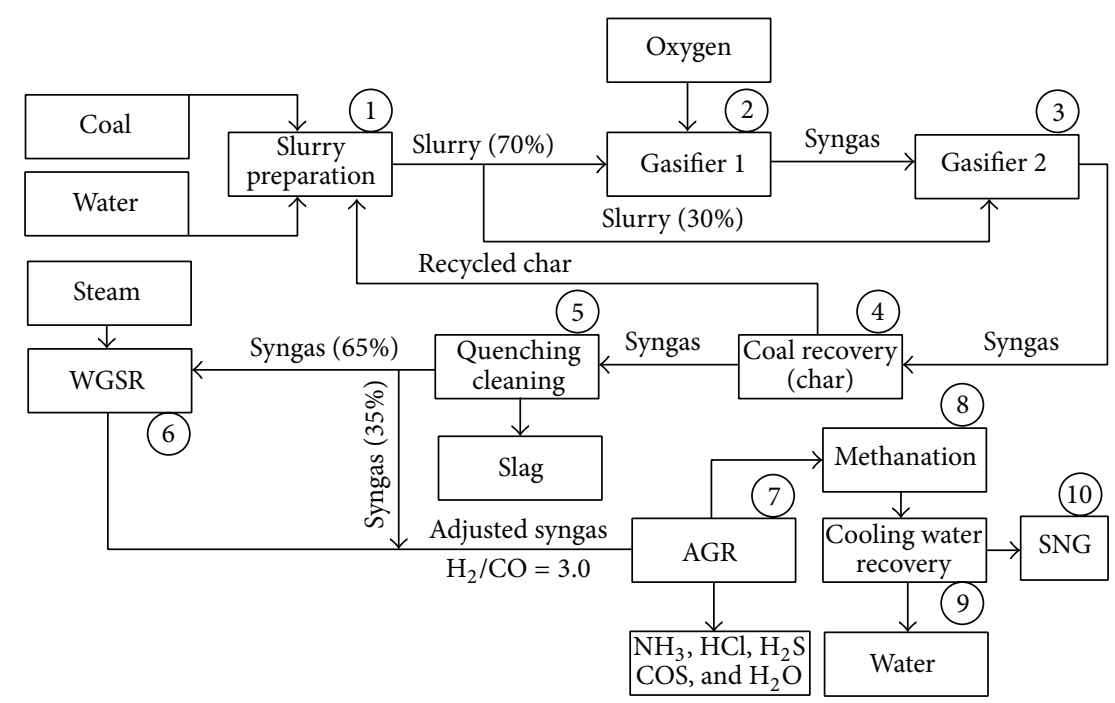

FIGURE 1: Process stages of SNG production via coal gasification using slurry feeding technology.

natural gas at temperatures around $50-60^{\circ} \mathrm{C}$ with high level concentrations of methane (SNG). Consider

$$
\begin{aligned}
\mathrm{CO}+3 \mathrm{H}_{2} & \Longleftrightarrow \mathrm{CH}_{4}+\mathrm{H}_{2} \mathrm{O} \\
\mathrm{CO}_{2}+4 \mathrm{H}_{2} & \Longleftrightarrow \mathrm{CH}_{4}+2 \mathrm{H}_{2} \mathrm{O}
\end{aligned}
$$

2.2. Coal-SNG Process Description: Dry Coal Feed Mode. The process diagram to produce SNG via coal gasification using an entrained flow reactor with dry feeding technology is presented in Figure 2. Stage 1 represents the fuel inlet to the system mixed with $\mathrm{CO}_{2}$ in an entrained flow gasifier. It should be noted that compared with the slurry feeding technology, this process require that the coal goes to the gasifier with very low moisture content, between $1 \%$ and $2 \%$. In the dry feeding technology, the gasifier includes just one reactor [26] (Stage 2, Figure 2). All remaining stages in the dry feeding technology correspond to the analogous stages that were described in the slurry feeding technology (Section 2.1). However, the amount of syngas that passes through the WGSR is different for both technologies. In the dry feeding technology, around $85 \%-$ $95 \%$ of the syngas mass flow goes through the WGRS and the remainder of the syngas is bypassed to acid gases recovery unit (AGR). This is because the syngas molar ratio $\mathrm{CO} / \mathrm{H}_{2}$ leaving the gasifier in slurry technology is around $1: 1$, while in dry technology the syngas $\mathrm{CO} / \mathrm{H}_{2}$ molar ratio is around $2: 1$. The higher $\mathrm{CO}$ concentration in the syngas leaving from the gasifier with dry feeding technology is attributed to the lower amount of water in the gasification process, which is directly related with the $\mathrm{H}_{2}$ concentration.

2.3. Test Fuels. The chemical characterization of the Colombian coals used in this study is presented in Table 1. According to the ASTMD88-12 standard, the Sanoha coal is classified as bituminous coal and Bijao coal is a subbituminous type B coal. These fuels are used to validate the model with technical data.
TABLE 1: Chemical characterization of Colombian coals (Bijao coal

\begin{tabular}{|c|c|c|}
\hline Characterization & Bijao & Sanoha \\
\hline \multicolumn{3}{|l|}{ Proximate analysis (wt.\% wet) } \\
\hline Ash (ASTM D 73174) & 6.5 & 14.8 \\
\hline Volatile matter (ASTM D 3175) & 45.89 & 29.85 \\
\hline Fixed carbon (ASTM D 3172) & 47.61 & 55.35 \\
\hline Moisture content (ASTM D 3302) & 19.05 & 4.93 \\
\hline \multicolumn{3}{|l|}{ Ultimate analysis (wt. \% dry) } \\
\hline $\mathrm{C}$ & 68.24 & 72.11 \\
\hline $\mathrm{H}$ & 4.9 & 4.78 \\
\hline $\mathrm{N}$ & 1.59 & 1.62 \\
\hline S (ASTM D 5865) & 1.36 & 1.44 \\
\hline $\mathrm{O}$ & 17.38 & 5.52 \\
\hline $\mathrm{Cl}$ & 0.03 & 0 \\
\hline Ash (ASTM D 73174) & 6.5 & 14.8 \\
\hline $\mathrm{HHV}_{\mathrm{d} . \mathrm{b}}(\mathrm{kcal} / \mathrm{kg})(\mathrm{ASTM} \mathrm{D} 5865)$ & 5407 & 7538 \\
\hline
\end{tabular}
and Sanoha coal) used in simulations.

2.4. Software Selection. Simulations were carried out using Advanced System for Process Engineering simulation software (Aspen Plus v7.3) [27]. Aspen Plus is a process modeling software suitable for a variety of steady state modeling applications. Currently, this software was widely applied in simulating gasification processes, cogeneration plants, and polygeneration systems, all of them with different technologies and fuels [12, 28-34], and good agreement between the industrial data and those determined using the Aspen models was obtained $[35,36]$. Aspen Plus software provides a flexible input language for describing the SNG production process, including its components, connectivity, and computational sequences. Use of Aspen Plus leads to an easier way of model development, maintenance, and updating since small sections of complex and integrated systems can be created and tested as separate modules before they are integrated. It 


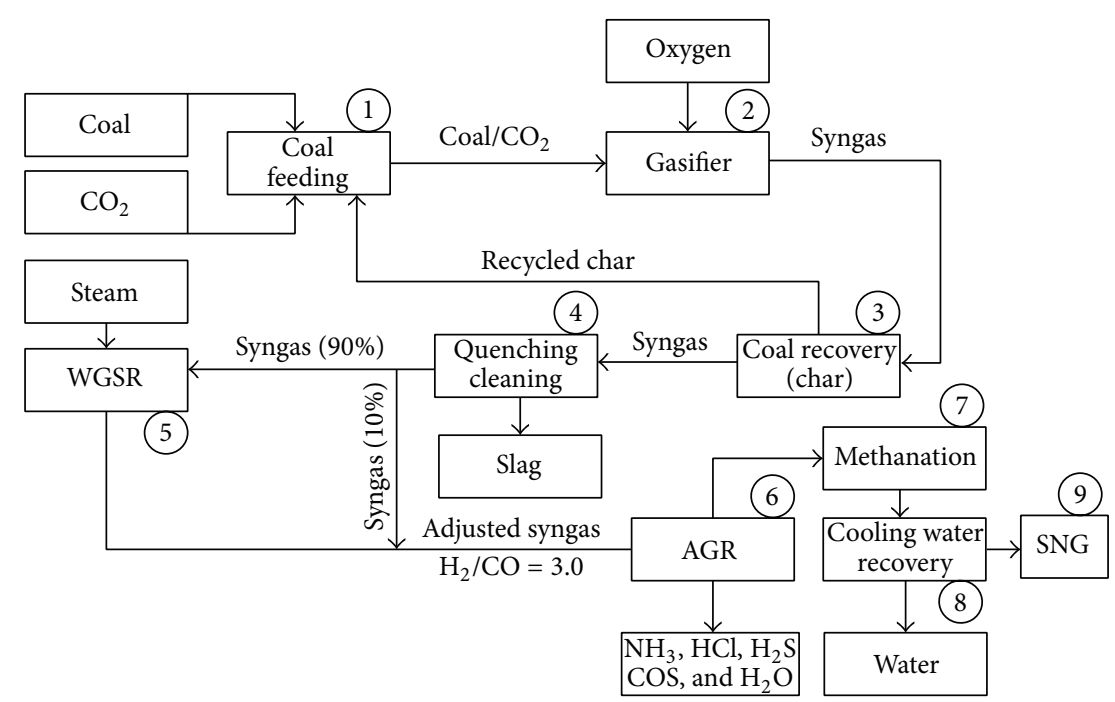

Figure 2: Process stages of SNG production via coal gasification using dry feeding technology.

has an extensive physical properties database to model the material streams in SNG production process $[6,30,33,37,38]$. Additionally, Aspen Plus has many built-in model blocks (such as heaters, pumps, stream mixers, and stream splitters), some of which can be directly used in this work.

\section{Aspen Plus Model Description}

3.1. Hypothesis. The relatively high temperatures used in the gasification process allow the consideration that the kinetic barriers are minimized and it was found that the gaseous mixtures leave from the gasifiers approach to the equilibrium $[4,39]$. Therefore, the gasification process can be successfully described by means of a thermodynamic model [27, 40]. In this work, an overall equilibrium approach is employed while neglecting the hydrodynamic complexity of the gasifier. Other assumptions in the model are: (1) stationary state, (2) WGSR and methanation reactor which are equilibriumisothermal reactors, (3) char which is supposed to be $100 \%$ graphite (conventional substance available in Aspen Plus database), (4) the ash content which is turned into slag, and (5) the gasifier reactors which are simulated as RGibbs adiabatic reactors. In addition, the conditioning coal (drying) and air separation unit to get oxygen as a gasifying agent are not considered in the model.

The RGibbs reactor was chosen because this kind of reactor can handle three phases under chemical equilibrium and allows predicting the equilibrium composition of the produced syngas by minimizing the Gibbs free energy [21]. Indeed, the RGibbs reactor of Aspen that works under the Gibbs free energy minimization principle has been widely adopted to represent gasification reactions [6, 41-43]. The equilibrium products potentially formed in the RGibbs reactors are $\mathrm{H}_{2} \mathrm{O}, \mathrm{N}_{2}, \mathrm{O}_{2}, \mathrm{H}_{2}, \mathrm{C}, \mathrm{CO}, \mathrm{CO}_{2}, \mathrm{CH}_{4}, \mathrm{H}_{2} \mathrm{~S}, \mathrm{NH}_{3}$, $\mathrm{COS}, \mathrm{HCl}$, and $\mathrm{Cl}_{2}[24,28]$. These species allow the versatile simulation of different kind of syngas, depending on the input parameters. Definition of species potentially formed in the gasifier was based on the following considerations. (i) $\mathrm{CH}_{4}$ is the only hydrocarbon taken into consideration in this work due to higher pressure and temperature [4]. (ii) The sulfur contained in the coal is assumed to be converted mainly into $\mathrm{H}_{2} \mathrm{~S}$ and COS. The low amounts of chlorine suggest that the chlorinated species formed are only traces of $\mathrm{HCl}$ and $\mathrm{Cl}_{2}$; and (iii) the assumption that only $\mathrm{NH}_{3}$ forms and not oxides of nitrogen are produced has already been made by other researchers [44].

3.2. Coal to SNG Model. This section discusses how Aspen Plus is used to simulate the SNG production via coal gasification using slurry feeding technology. Also, the main differences are described in the modeling approach for dry feeding technology. The Aspen Plus process flow sheet is divided into five hierarchies (Figure 3): slurry preparation (FEEDING), gasification (GASIFIC), water gas shift reactor (SHIFTING), acid gas recovery unit (AGR), and methanation (METHANAT). Each one of these hierarchies includes at least one Aspen Plus built-in block, and in some cases, that is, in the FEEDING hierarchy, there are also included additional Fortran subroutines.

In the case of dry feeding technology, the main process diagram is quite similar to the one shown in Figure 3. In the flow sheet of the dry feeding technology, the WATER inlet stream is replaced by a $\mathrm{CO}_{2}$ inlet stream. Differences between the models of both feeding modes are appreciated inside some specific hierarchies that are described below.

3.2.1. FEEDING Hierarchy. The Aspen Plus model used for simulating the slurry preparation (FEEDING hierarchy) is showed in Figure 4.

FEEDING hierarchy (Figure 4) is used to simulate the raw material inlet to the process (Stream COAL) which is composed only by coal as received in the plant; that is, neither crushing processes nor drying processes are considered. The feedstock is Colombian coal with the proximate analysis and 


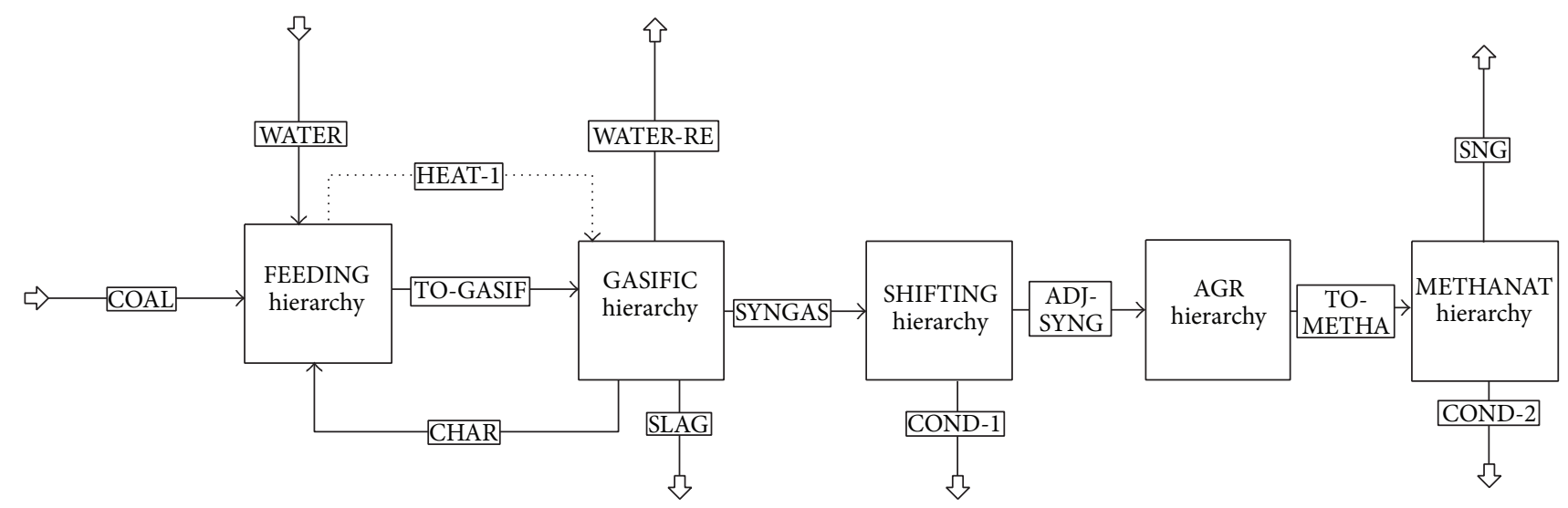

FIGURE 3: Aspen Plus process flow sheet for SNG production via coal gasification using slurry feeding technology (ConocoPhillips 66).

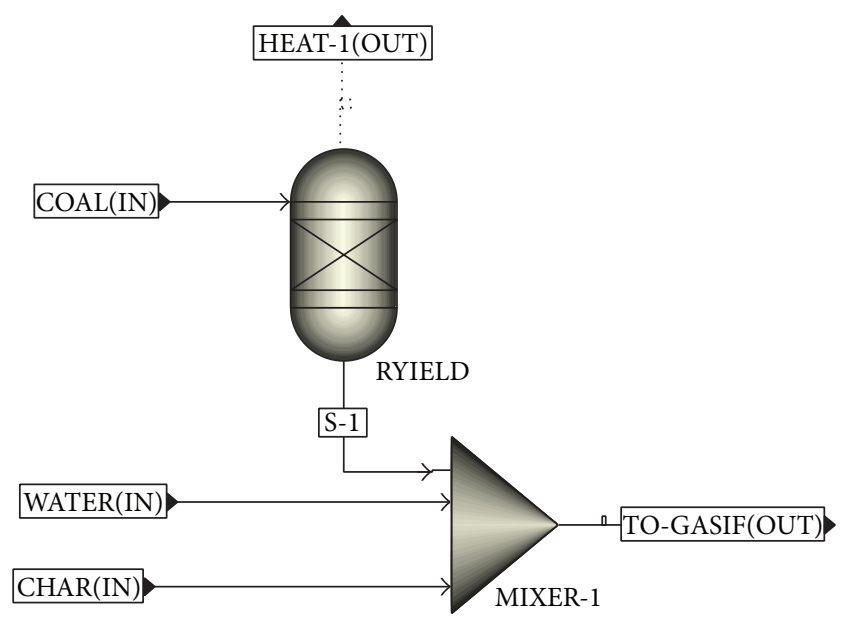

Figure 4: Aspen Plus feeding hierarchy for the simulation of the slurry preparation in the SNG production via coal gasification.

ultimate analysis given in Table 1. Aspen Plus cannot handle nonconventional substances, and coal is a nonconventional solid with a complex macromolecular structure $[45,46]$. Therefore, the coal stream needs to be hypothetically decomposed in reactive compounds, that is, its corresponding constituents (such as $\mathrm{C}, \mathrm{H}_{2}, \mathrm{~N}_{2}, \mathrm{O}_{2}, \mathrm{~S}, \mathrm{Cl}_{2}$, and $\mathrm{H}_{2} \mathrm{O}$ ), based on its proximate analysis and ultimate analysis. This is performed in a yield reactor (RYIELD block, Figure 4) [41, 43-46]. The yield distribution for this reactor has been specified by FORTRAN statements in a calculator block [47]. These statements specify the mass flow rates of the components in the stream S-1, Figure 4. The slurry is then formed by mixing the stream S-1 with the inlet stream WATER in the mixer block MIXER-1, and it is driven to the next process stage through the stream TO-GASIF (Figure 4). The stream TO-GASIF leaves from the FEEDING hierarchy and becomes the main inlet to the GASIFIC hierarchy, where the formation, quenching, conditioning, and cleaning of the syngas are simulated. In the built-in mixer block (MIXER1), the unreacted solid coal (char) from the gasification process stage is reentered to the process. By the other side regarding the energy, the heat of reaction associated with the coal decomposition is carried by the heat stream HEAT1 (Figure 4) into the next hierarchy (GASIFIC, Figure 3) $[25,30]$, where gasification reactions have been modeled [47]. Then, further gasification reactions were applied to the available constituents of the coal at the same enthalpy level.

When dry feeding technology is simulated, the Aspen Plus flow sheet for FEEDING hierarchy is quite similar to that described in Figure 4; the only difference is the use of a $\mathrm{CO}_{2}$ inlet stream instead of the WATER inlet stream, taking into account the lower moisture content of the raw material (1\%$2 \%)$.

3.2.2. GASIFIC Hierarchy. Figure 5 is a schematic diagram of the Aspen Plus model for the gasifier facility $[48,49]$. The gasification facility consists of three sections: a reactor, quenching, and cleaning systems (solids and liquid removing from the syngas). In the modeled slurry technology, the gasification system is comprised of two RGibbs reactors (RGIBB-1 and RGIBB-2, Figure 5). The stream TO-GASIF coming from FEEDING hierarchy is split into two streams by a stream divisor block (SPLIT1). The formed streams S-2 and S-3 (Figure 5) carry on the $70 \%$ wt. and 30\% wt. (resp.) of the total material coming in the stream TO-GASIF. In the same way, the heat stream HEAT-1 is divided in two heat streams H-2 and H-3 with a stream divisor block (QSPLIT), Figure 5. The stream S-2 reacts with the inlet stream OXYGEN in the RGIBB-1 reactor. The mass flow of the OXYGEN stream can be adjusted in order to modify the equivalence ratio (ER) (see (7)) or the reactor temperature. The stream S-4 (Figure 5) feeds the second RGibbs reactor RGIBB-2 and reacts with the stream S-3. In this way, the formation of $\mathrm{H}_{2}, \mathrm{CH}_{4}$ and $\mathrm{CO}$ is promoted; see (1)-(3). The stream S-5 (Figure 5) is then quenched and cooled by mixing it with water from the inlet stream WATQFEED in the Aspen Plus built-in blocks MIXER-2 and HEATER-1. The next step is the block SSPLIT, it is used to simulate a stream divisor. SSPLIT is an Aspen Plus built-in block that allows completely separating conventional from no conventional compounds as well as solids from liquids and gases. Thus, the SSPLIT separates conventional solids and unconventional solids and the gaseous phase 


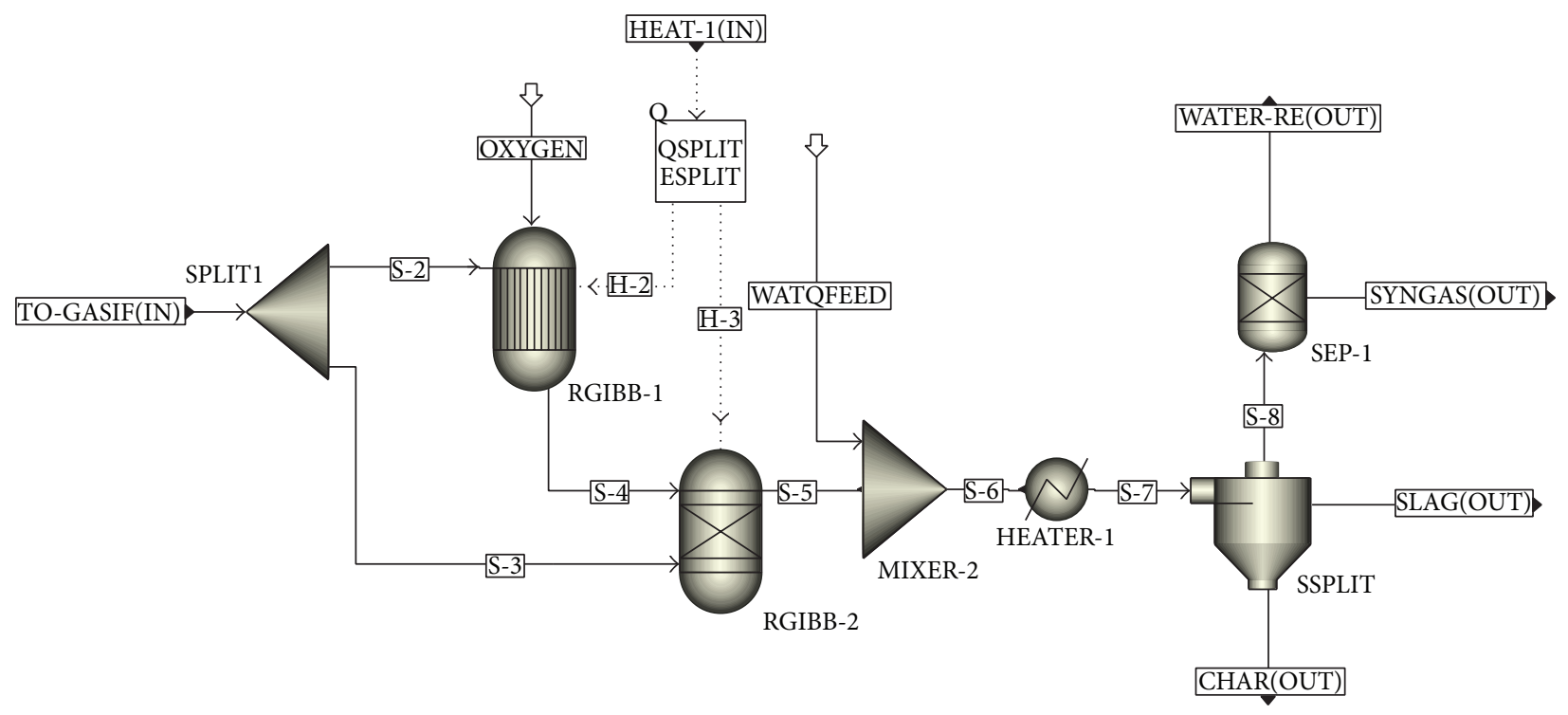

FIGURE 5: Aspen Plus GASIFIC hierarchy diagram to simulate the gasification stage of coal-SNG process. Flow sheet for the slurry feeding technology.

coming from the reactor $[6,47]$. The conventional solids correspond to the unreacted coal or char (stream CHAR), and the unconventional solids are mainly ash (stream SLAG). Stream CHAR is recycled and fed back into the process in the FEEDING hierarchy; in contrast, the stream SLAG is discharged from the process. The remaining wet gaseous mixture (stream S-8, Figure 5) is then driven to the SEP1 block where water recovery is simulated and the cleandry syngas is driven to the next SHIFTING hierarchy. SEP units used in this model are Aspen Plus built-in blocks which separate substances from a mixture by means of mass and energy balances criteria without any thermodynamic equilibrium calculation. In several commercial gasifiers, quenching is used for gas cooling and promotion of slag formation. The water in the WATER-RE stream can be conditioned and reused in the WATQFEED or the WATER inlet streams.

This developed model is useful to predict the syngas composition and reactor temperature under various operating conditions, including flow rates, composition, and temperature of the feed materials as well as the operating reactor pressure.

To simulate the dry feeding technology, the Aspen Plus flow sheet for GASIFIC hierarchy uses just one RGibbs reactor; hence neither mass splitters nor heat splitters are introduced into the model, and the full TO-GASIF stream as well as the full HEAT-1 stream goes to the RGIBB-1 reactor; see Figure 6. Despite this, all the remaining built-in blocks in the dry feeding technology (Figure 6) correspond to the analogous stages that are described in the slurry feeding technology (Figure 5).

3.2.3. SHIFTING Hierarchy. The syngas coming out from GASIFIC hierarchy is sent to the SHIFTING hierarchy, where the WGSR is simulated. As shown in Figure 7, the bypass is simulated by means of a built-in stream splitter block (SPLIT2 ). The stream S-9, in the slurry feeding technology, carries between $60 \%$ and $70 \%$ of SYNGAS stream to the REQUIL reactor. In this reactor, the water gas shift reaction (see (4)) takes place. The stream S-11 leaving the WGSR reactor and stream S-10 (bypass) are mixed and cooled in the HEATER2 built-in block. The mass flow of the inlet stream STEAM is adjusted until a molar ratio $\mathrm{H}_{2} / \mathrm{CO}=3$ in the stream ADJ-SYNG. To adjust this ratio, the sensitivity analysis tool supported by Aspen Plus was used. This tool is in the section model analysis. The stream ADJ-SYNG leaves the SHIFTING hierarchy and feeds the AGR hierarchy, where gas cleaning process is simulated.

A similar flow sheet presented in Figure 7 is used to simulate the water gas shift process of the dry feeding technology. The process takes into account that through stream S-9 flows around the $85 \%-95 \%$ of SYNGAS stream, while the remaining mass flow bypasses the WGSR reactor through stream S-10.

3.2.4. AGR Hierarchy. In this model, the acid gases recovery unit is modeled by means of a built-in SEP block (SEP-2). The clean-up process is simulated for the syngas by retiring all acid gases and other impurities formed upstream in the process, Figure 8 . This stage is similar to both technologies simulated (dry and slurry).

As shown in Figure 8, the ADJ-SYNG stream coming from SHIFTING hierarchy is separated into ACID-G stream (composed by $\mathrm{H}_{2} \mathrm{O}, \mathrm{N}_{2}, \mathrm{H}_{2} \mathrm{~S}, \mathrm{NH}_{3}, \mathrm{CO}_{2}$, and $\mathrm{COS}$ ) and TOMETHA stream, which is composed mainly by $\mathrm{CH}_{4}, \mathrm{CO}$ and $\mathrm{H}_{2}$. The stream TO-METHA feeds the next hierarchy where methanation reaction is simulated.

3.2.5. METHANAT Hierarchy. The stream TO-METHA upcoming from the AGR hierarchy is driven to 


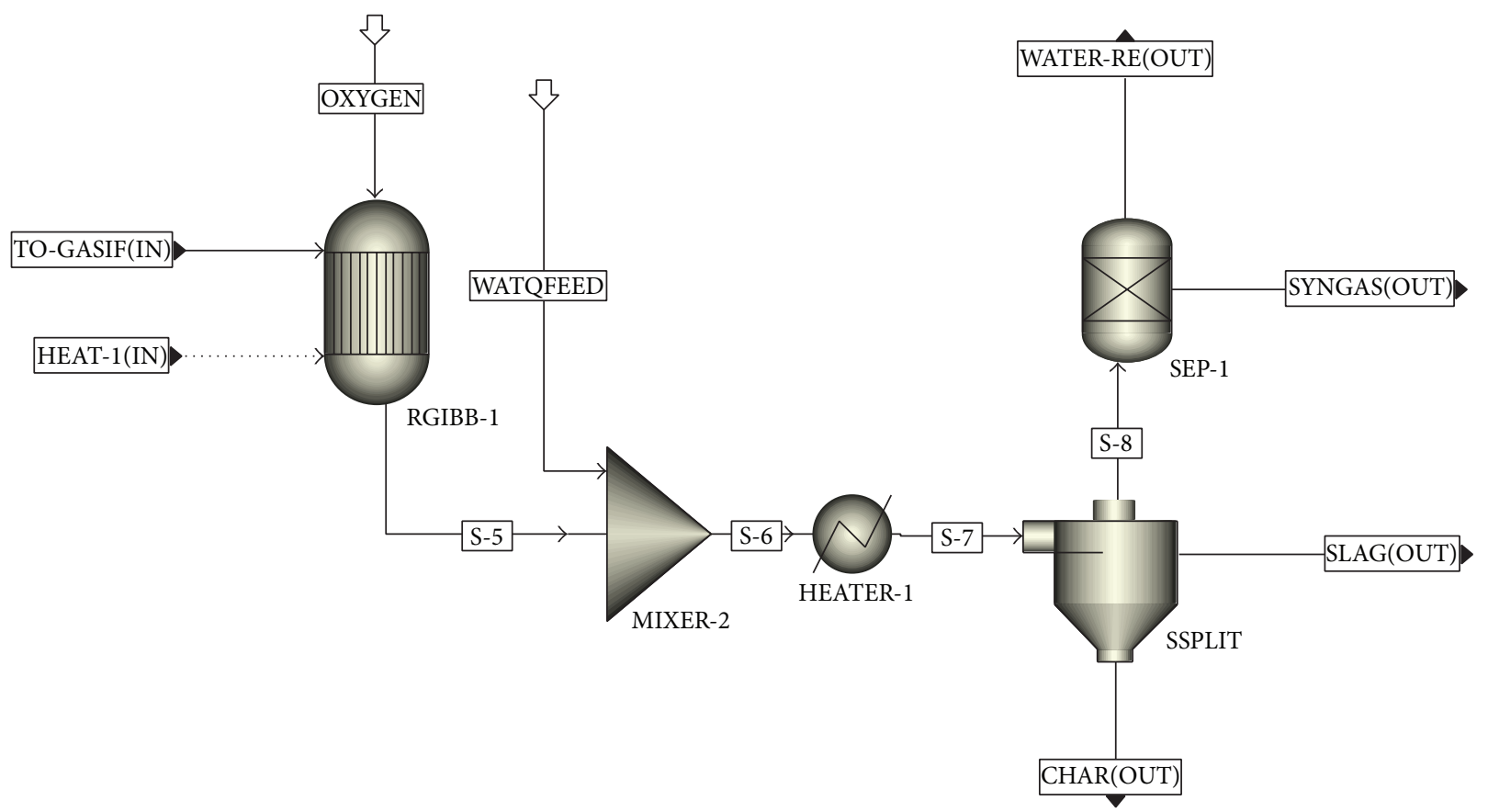

FIGURE 6: Aspen Plus GASIFIC hierarchy diagram to simulate the gasification stage of coal-GNS process. Flow sheet for dry feeding technology.

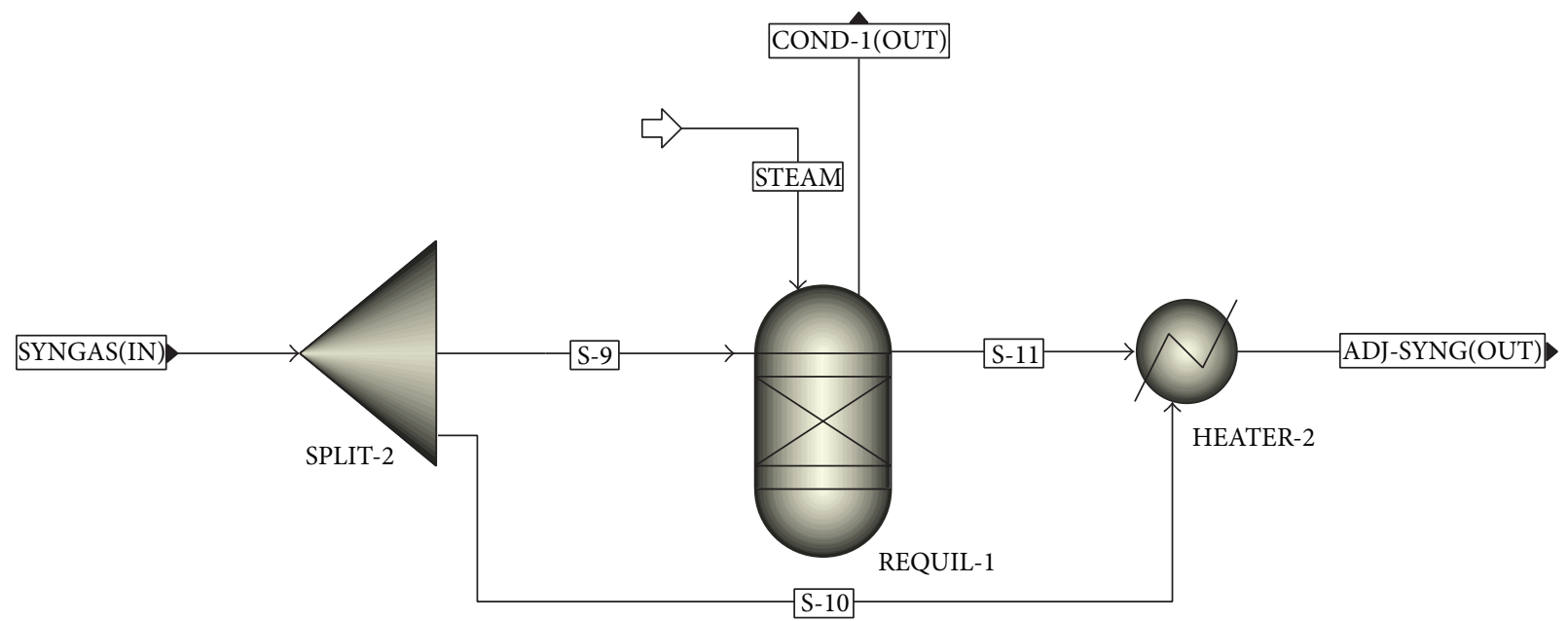

FIGURE 7: Aspen Plus SHIFTING hierarchy diagram to simulate the WGSR stage in the coal-SNG process.

the METHANAT hierarchy, where promotion of methane formation is simulated. As shown in Figure 9, the stream TO-METHAN is fed into an equilibrium reactor (REQUIL2), where $\mathrm{CO}$ and $\mathrm{H}_{2}$ react to form $\mathrm{CH}_{4}$ and $\mathrm{H}_{2} \mathrm{O}$ (see (5)). Condensates are retired by stream S-14, while gaseous products are driven by stream S-12 into a heater (HEATER-3) where the gases are cooled and sent to SEP unit (SEP-3). In the SEP-3 separator, the split process between SNG and water is simulated. $\mathrm{CO}_{2}$ and any other possible remaining impurities are retired by stream S-15. In this way, the stream SNG (Figure 9) contains the desired gaseous product with high methane concentration.
In this hierarchy, there are no model process differences between the slurry feeding and the dry feeding technology; thus, the dry feeding technology is simulated using the same diagram model (Figure 9).

3.3. Energy Parameters. Energy indicators were estimated to characterize the SNG production via coal gasification using Colombian coals as raw material. These parameters are useful to analyze the process in function of the feeding fuel system technology. The description of such energy indicators is given below. 


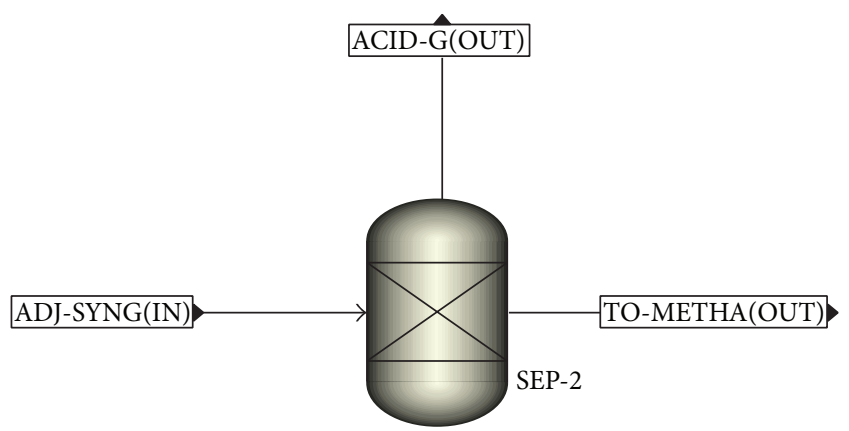

FIGURE 8: Aspen Plus AGR hierarchy diagram to simulate the acid gases clean-up in the coal-SNG process.

(i) Equivalence ratio (ER), (7), accounts for the oxygen/coal ratio in the thermochemical process. ER $>1$ represents a poor-fuel process while ER $<1$ indicates a richfuel process or incomplete combustion. ER $=1$ indicates stoichiometric combustion, where all the fuel in the gasifier is completely oxidized and transformed into $\mathrm{H}_{2} \mathrm{O}$ and $\mathrm{CO}_{2}$. Consider

$$
\mathrm{ER}=\frac{\left(\dot{m}_{\mathrm{O}_{2}} / \dot{m}_{\text {coal }}\right)}{\mathrm{ER}_{\mathrm{stq}}}
$$

where $\dot{m}_{\mathrm{O}_{2}}$ and $\dot{m}_{\text {coal }}$ are the inlet mass flows of oxygen and coal, respectively. $\mathrm{ER}_{\text {stq }}$ is the stoichiometric equivalent ratio (see (8)) calculated with the theoretical combustion reaction (see (9)). Consider

$$
\begin{gathered}
\mathrm{ER}_{\text {stq }}=\frac{\varphi \cdot M_{\mathrm{O}_{2}}}{M_{\text {coal }}}, \\
\mathrm{C}_{n} \mathrm{H}_{m} \mathrm{O}_{p} \mathrm{~N}_{q} \mathrm{~S}_{r}+\varphi \mathrm{O}_{2} \longrightarrow a \mathrm{CO}_{2}+b \mathrm{H}_{2} \mathrm{O}+d \mathrm{~N}_{2}+f \mathrm{SO}_{2},
\end{gathered}
$$

where $\mathrm{C}_{n} \mathrm{H}_{m} \mathrm{O}_{p} \mathrm{~N}_{q} \mathrm{~S}_{r}$ represents a recursive fuel substitution formula estimated in dry base and ash free; $\varphi=n+m / 4+$ $r / 2-p / 2 ; M_{\mathrm{O}_{2}}$ and $M_{\text {coal }}$ are the molecular weight of oxygen and coal, respectively.

(ii) Coal Conversion efficiency (CCE, \%), (10), is the ratio between the amount (mass units) of SNG at the exit of the process and the amount (mass units) of coal at the inlet of the process. Consider

$$
\mathrm{CCE}=\frac{\dot{m}_{\mathrm{SNG}}}{\dot{m}_{\mathrm{coal}}} \times 100
$$

with $\dot{m}_{\mathrm{SNG}}$ the mass flow of substitute natural gas leaving the process.

(iii) Cold gas efficiency $\left(\eta_{\mathrm{cg}}, \%\right)$, or the energy efficiency of the gasification process, (11), is the ratio between the syngas energy in the stream leaving from the gasifier and the coal energy in the stream feeding into the process. Consider

$$
\eta_{\text {cg }}=\frac{\dot{m}_{\text {syngas }} \cdot \mathrm{HHV}_{\text {syngas }}}{\dot{m}_{\text {coal }} \cdot \mathrm{HHV}_{\text {coal }}} \times 100 \text {, }
$$

TABLE 2: High heating values of the gaseous species considered in the syngas leaving from the gasifier [50].

\begin{tabular}{lcc}
\hline Gaseous specie & $\mathrm{HHV}\left(\mathrm{M} J / \mathrm{Nm}^{3}\right)$ & $\mathrm{HHV}(\mathrm{MJ} / \mathrm{kg})$ \\
\hline $\mathrm{CO}$ & 12.622 & 10.1 \\
$\mathrm{H}_{2}$ & 12.769 & 141.8 \\
$\mathrm{CH}_{4}$ & 39.781 & 55.53 \\
$\mathrm{C}_{2} \mathrm{H}_{4}$ & 63 & 50.2952 \\
$\mathrm{C}_{6} \mathrm{H}_{6}$ & 142.893 & 41.8 \\
$\mathrm{H}_{2} \mathrm{~S}$ & 25.105 & 16.488 \\
$\mathrm{NH}_{3}$ & 13.072 & 22.428 \\
\hline
\end{tabular}

where $\dot{m}_{\text {syngas }}$ is the mass flow of syngas leaving from the gasifier; $\mathrm{HHV}_{\text {coal }}$ is the higher heating value of coal as received that is including ash and moisture contents; $\mathrm{HHV}_{\text {syngas }}$ is the higher heating value of the syngas stream leaving the gasifier (wet basis), (12). Consider

$$
\mathrm{HHV}_{\text {syngas }}=\sum_{i=1}^{k} X_{i} \cdot \mathrm{HHV}_{i}
$$

with $X=$ mass fraction (wet basis); $i=$ each one of the gaseous species with energy contents considered in the syngas, that is, $\mathrm{CO}, \mathrm{H}_{2}, \mathrm{CH}_{4}, \mathrm{C}_{2} \mathrm{H}_{4}, \mathrm{C}_{6} \mathrm{H}_{6}, \mathrm{H}_{2} \mathrm{~S}$, and $\mathrm{NH}_{3} ; \mathrm{HHV}_{i}$ values are taken from the literature and are presented in Table 2 [50].

(iv) Process efficiency ( $\left.\eta_{\text {pro }}, \%\right),(13)$, is the energy efficiency of the conversion of the syngas to SNG, estimated as the ratio between energy of SNG on the stream leaving the process and syngas energy on the stream leaving the gasifier, where $\mathrm{HHV}_{\mathrm{SNG}}$ is the higher heating value of the SNG. Consider

$$
\eta_{\text {pro }}=\frac{\dot{m}_{\mathrm{SNG}} \cdot \mathrm{HHV}_{\mathrm{SNG}}}{\dot{m}_{\text {syngas }} \cdot \mathrm{HHV}_{\text {syngas }}} \times 100 .
$$

(v) Global efficiency $\left(\eta_{\text {global }}, \%\right),(14)$, is defined as the ratio between energy on the SNG stream leaving the process and energy in the coal stream feeding the process, that is, energy efficiency of the coal conversion to SNG. Consider

$$
\eta_{\text {global }}=\frac{\dot{m}_{\mathrm{SNG}} \cdot \mathrm{HHV}_{\mathrm{SNG}}}{\dot{m}_{\text {coal }} \cdot \mathrm{HHV}_{\text {coal }}} \times 100=\eta_{\mathrm{cg}} \cdot \eta_{\text {pro }}
$$

(vi) High heating value of the SNG $\left(\mathrm{HHV}_{\mathrm{SNG}}\right)$, (15), accounts for the quality of the gas leaving the process. It is estimated from the molar fraction of gaseous products with energy content in the SNG stream. Consider

$$
\mathrm{HHV}_{\mathrm{SNG}}=\sum_{j=1}^{n} Y_{j} \cdot \mathrm{HHV}_{j}
$$

with $Y=$ molar fraction; $j=$ each one of the gaseous species with energy content considered in the SNG, that is, $\mathrm{CO}, \mathrm{H}_{2}$, and $\mathrm{CH}_{4}$.

(vii) Wobbe Index, WI $\left(\mathrm{MJ} / \mathrm{Nm}^{3}\right)$, (16), accounts for the exchangeability of gases. According to the Wobbe Index, it is possible to know if the SNG quality is good enough to be 


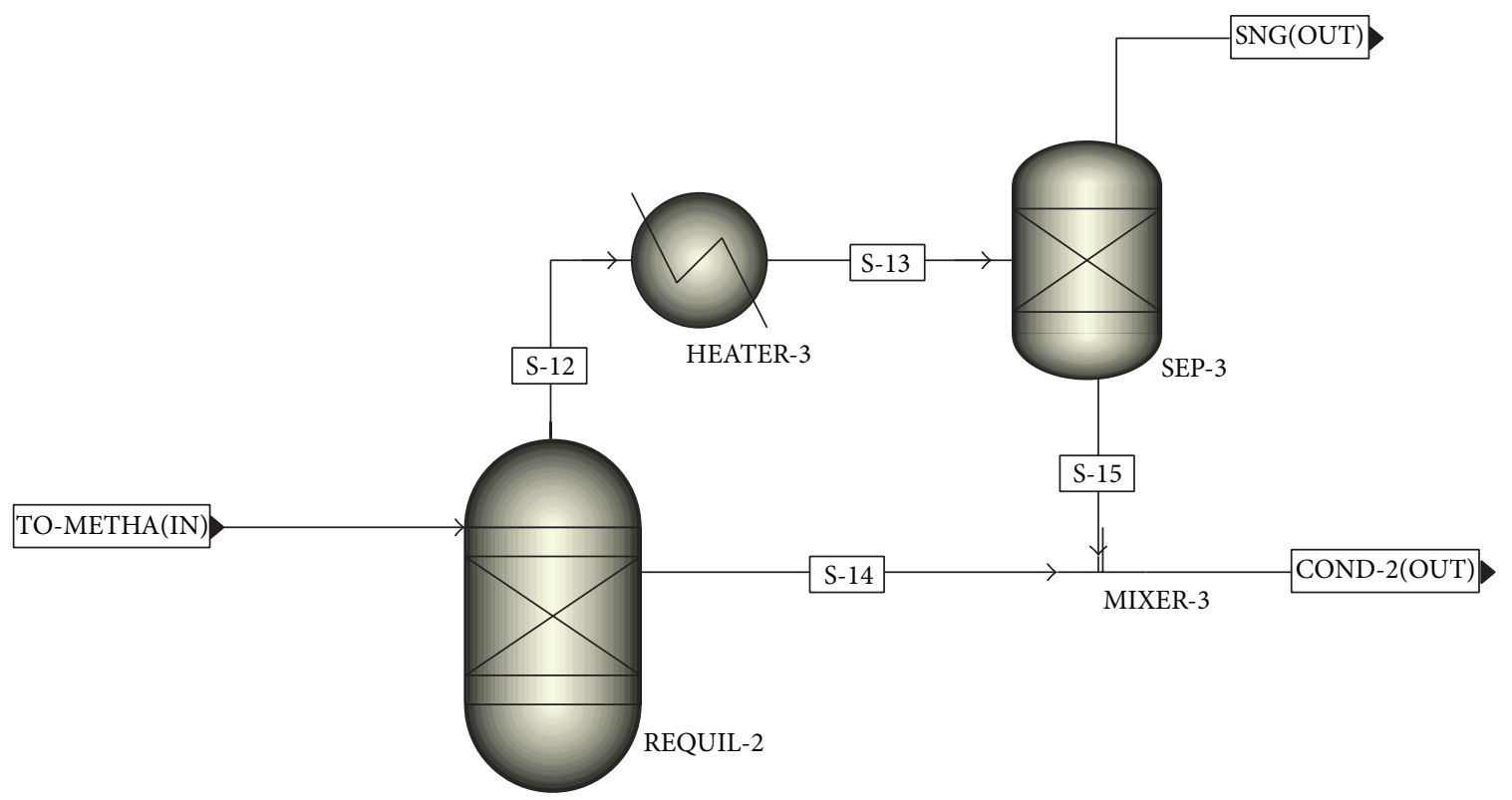

FIGURE 9: Aspen Plus METHANAT hierarchy diagram to simulate the methanation reaction in the cola-SNG process.

transported by gas pipe lines, with density $(\rho)$ at standard conditions $\left(1 \mathrm{~atm}, 15^{\circ} \mathrm{C}\right)$. Consider

$$
\mathrm{WI}=\frac{\mathrm{HHV}_{\mathrm{SNG}}}{\sqrt{\rho_{\mathrm{SNG}} / \rho_{\mathrm{air}}}}
$$

(viii) Power, $P(\mathrm{~kW}),(17)$, is a parameter referring to $\mathrm{SNG}$ power, and it is estimated as the product between SNG mass flow rate produced $\left(\dot{m}_{\mathrm{SNG}}, \mathrm{kg} / \mathrm{s}\right)$ and its higher heating value $\left(\mathrm{HHV}_{\mathrm{SNG}}, \mathrm{kJ} / \mathrm{kg}\right)$. Consider

$$
P=\dot{m}_{\mathrm{SNG}} \cdot \mathrm{HHV}_{\mathrm{SNG}} \text {. }
$$

3.4. Simulation Conditions. The mass flow rates presented in Table 3 are used to validate the model. The aim is to analyze the model accuracy in order to simulate the SNG production via coal gasification. The operation conditions (i.e., temperature and pressure) for reactors and other facilities (Table 4) were taken from the available technical report [51] or assumed in this work according to the literature or simulation results. The simulation conditions are defined to produce around 100 MMFCD SNG. Therefore, the pressure of the gasifier is higher than 40 bar due to the objective of this work being the study of a real and feasible process [52].

The energy parameters, such as $\mathrm{HHV}_{\text {syngas }}$ and $\mathrm{HHV}_{\mathrm{SNG}}$, coal conversion efficiency, cold efficiency, process efficiency, global efficiency, Wobbe Index, and power (see (12)-(17)), were directly estimated within the Aspen Plus model by means of Fortran statements in calculator blocks. The equivalence ratio was estimated as an operation condition of the gasifier and thus the reaction temperatures.

\section{Results and Discussion}

In this section, the simulation results for SNG synthesis with two Colombian coals (Bijao and Sanoha) are compared with available data from the technical report using slurry and dry feeding technologies [51]. Simulation results include the syngas and the SNG compositions, SNG flows (mass and volumetric flows), and energy parameters. These results are useful to compare the feeding technologies as well as fuel specifications (Colombian coal rank) in the SNG production via coal gasification.

Two global parameters to estimate the quality of simulation results and to compare with reference data are proposed in different works, the root mean square deviation (RMSD) or root mean square error (RMSE) and the relative error (RE) $[53,54]$. These parameters are considered in this work to analyze the model accuracy against the reference data. The RMSD has the units of each parameter analyzed and the RE is expressed in percentage (\%). The RE is presented as the average error between estimated and reported amount of each gaseous specie in the syngas, for both coal types and both feeding technologies. Consider

$$
\begin{aligned}
\mathrm{RMSD} & =\sqrt{\frac{\sum_{i=1}^{n}\left(X_{\text {reference }, i}-X_{\text {model }, i}\right)^{2}}{n},} \\
\mathrm{RE} & =\left|\frac{X_{\text {reference, } i}-X_{\text {model }, i}}{X_{\text {reference }, i}}\right| \cdot 100 .
\end{aligned}
$$

4.1. Syngas and SNG Composition. The simulated syngas composition for both feeding technologies is validated by comparison with technical report data and it is shown in Table 5. To estimate the model behavior, the RMSD and the RE are presented in the same table. Both comparative parameters have been estimated for each specie in the gas (syngas and SNG) including the coal type and feeding technology in the same calculus.

The coherent behavior of the model to predict the species with higher concentration in the syngas stream is observed. 
TABLE 3: Mass flow rates used in the model as inlet streams.

\begin{tabular}{lcccccc}
\hline Technology feeding & Raw material & Coal $($ ton $/ \mathrm{h})$ & Water $($ ton $/ \mathrm{h})$ & Oxygen $($ ton $/ \mathrm{h})$ & $\mathrm{CO}_{2}($ ton $/ \mathrm{h})$ & Steam $($ ton $/ \mathrm{h})$ \\
\hline \multirow{2}{*}{ Slurry } & Bijao & 293.6 & 126.3 & 173.9 & - & $86.7^{*}$ \\
& Sanoha & 219.5 & 107.1 & 138.02 & - & $105^{*}$ \\
\multirow{2}{*}{ Dry } & Bijao & 237.2 & - & 175.2 & 143.5 & $189^{*}$ \\
& Sanoha & 220.4 & - & 188 & 138.2 & $192.7^{*}$ \\
\hline
\end{tabular}

* Estimated in this work, using sensitivity analysis, to reach the ratio $\mathrm{H}_{2} / \mathrm{CO}=3$.

TABLE 4: Reactors temperature and pressure conditions, inlet streams, and other model facilities described in the Aspen Plus models.

\begin{tabular}{lcc}
\hline Facility or inlet stream & Temperature $\left({ }^{\circ} \mathrm{C}\right)$ & Pressure $($ bar $)$ \\
\hline Coal stream & 27 & 5 \\
Water stream & 40 & 74.1 \\
Oxygen stream & 100 & 83 \\
$\mathrm{CO}_{2}$ stream & $250^{*}$ \\
Steam stream & Bijao coal: $1658^{* *}$ \\
\hline Reactor RGIBB-1 (Figure 5) & Sanoha coal: $1413^{* *}$ \\
Reactor RGIBB-2 (Figure 5) & Bijao coal: $940^{* *}$ \\
& Sanoha coal: $922^{* *}$ \\
Reactor RGIBB-1 (Figure 6) & Bijao coal: $1340^{* *}$ \\
Reactor REQUIL-1 (Figure 7) & Sanoha coal: $1508^{* *}$ \\
Reactor REQUIL-2 (Figure 9) & $250^{*}$ (Bijao and Sanoha coals) \\
\hline Heater HEATER-1 (Figure 5) & $350^{*}$ (Bijao and Sanoha coals) \\
Heater HEATER-1 (Figure 6) & 202 \\
Heater HEATER-2 (Figure 7) & 167 \\
Heater HEATER-3 (Figure 9) & 40 \\
\hline
\end{tabular}

*Adapted from [25]. ** Simulation results.

The $\mathrm{RE}$ of $\mathrm{H}_{2}$, $\mathrm{CO}$, and $\mathrm{CO}_{2}$ between simulated and reference data varies from $6.6 \%$ to $18 \%$. This is confirmed in Table 5 by the lower RMSD of the volumetric concentration of these gaseous species. For example, the RMSD of $\mathrm{H}_{2}$ indicates that the model prediction varies $\pm 5.3 \% \mathrm{vol}$; this value is lower compared with the $\mathrm{H}_{2}$ concentration produced in the entrained flow gasifiers simulated. The RMSD of CO and $\mathrm{CO}_{2}$ behaves in a similar way. Nevertheless, the model cannot predict with accuracy the species with lower concentration (traces of $\mathrm{N}_{2}, \mathrm{CH}_{4}, \mathrm{NH}_{3}$, and $\mathrm{COS}$ ) in the syngas due to their higher RE. This is also corroborated with the RMSD showed in Table 5. The model variability is higher against the traces concentrations reached in the gasification technologies simulated.

It is important to highlight that the temperature operation of the gasifier was not available in the reference work and thus could be an important deviation source between the reference and simulated data.

Regarding the $\mathrm{HHV}_{\text {syngas }}$ (wet basis), a fundamental energy parameter to characterize the gasification process, it is highlighted that the model is able to predict coherently this factor, because its RE is $13 \%$ and its RMSD varies in $\pm 1.6 \mathrm{MJ} / \mathrm{Nm}^{3}$. The higher heating value is around $10 \mathrm{MJ} / \mathrm{Nm}^{3}$ for both raw materials and both technologies simulated. These results are quite similar to other coal gasification reports that use the chemical equilibrium approach for their simulations [24].

Despite the low accuracy of the model to estimate traces but considering the $\mathrm{HHV}_{\text {syngas }}$ as global parameter of the process, it is possible to state that the gasification model behaved coherently under different coal types and feedstock feeding technologies.

Table 6 compares the composition of SNG between simulated conditions in this work and reported data [51]. Table 7 shows the mass and volumetric flows of SNG produced as well as the $\mathrm{HHV}_{\mathrm{SNG}}$ (see (15)), Wobbe Index (see (16)), and power (see (17)).

Methane concentrations in the simulated SNG are comparable for both technologies (Table 6) independent of coal type. The average RMSD of SNG composition is $\pm 1.8 \% \mathrm{vol}$ and the average relative error between reported and simulated data is lower than $2 \%$. However, the yield of $\mathrm{CH}_{4}$ with slurry feeding technology tends to be slightly higher due to the two gasification stages. Methane composition in the SNG simulated for both technologies is closer to Colombian natural gas composition from the Guajira region (around $97 \%$ vol of $\mathrm{CH}_{4}$ ).

On the other hand, in all simulated cases the model is not able to predict the traces concentration of $\mathrm{H}_{2}, \mathrm{~N}_{2}$, and $\mathrm{CO}_{2}$ in the SNG stream. The RE of simulated data for 
TABLE 5: Validation of syngas composition (vol\% dry base) for two different Colombian coals under slurry and dry feeding technologies.

\begin{tabular}{|c|c|c|c|c|c|c|c|c|c|c|}
\hline \multirow{3}{*}{$\begin{array}{l}\text { Syngas } \\
\left(\% \text { vol }_{\text {d.b }} .\right)\end{array}$} & \multicolumn{4}{|c|}{ Slurry feeding } & \multicolumn{4}{|c|}{ Dry feeding } & \multirow{3}{*}{$\begin{array}{l}\text { RMSD } \\
\text { (units) }\end{array}$} & \multirow{3}{*}{$\begin{array}{l}\overline{\mathrm{RE}}^{*} \\
(\%)\end{array}$} \\
\hline & \multicolumn{2}{|c|}{ Bijao } & \multicolumn{2}{|c|}{ Sanoha } & \multicolumn{2}{|c|}{ Bijao } & \multicolumn{2}{|c|}{ Sanoha } & & \\
\hline & {$[51]$} & Model & {$[51]$} & Model & {$[51]$} & Model & {$[51]$} & Model & & \\
\hline $\mathrm{N}_{2}$ & 0.61 & 0.35 & 0.6 & 0.3 & 1.27 & 0.628 & 1.26 & 0.61 & 3.6 & 48.7 \\
\hline $\mathrm{H}_{2}$ & 37.10 & 35.39 & 30.9 & 38.52 & 26.06 & 20.58 & 26.25 & 20.19 & 5.3 & 18.3 \\
\hline $\mathrm{CO}$ & 37.88 & 37.07 & 44.9 & 42.27 & 64.49 & 69.45 & 65.29 & 72.41 & 3.3 & 6.6 \\
\hline $\mathrm{CO}_{2}$ & 20.64 & 22.08 & 14.0 & 13.98 & 7.6 & 8.80 & 6.61 & 6.26 & 1.5 & 7.1 \\
\hline $\mathrm{CH}_{4}$ & 3.24 & 3.89 & 9.0 & 3.74 & 0.01 & 0.02 & 0.01 & 0.01 & 2.7 & 44.6 \\
\hline $\mathrm{H}_{2} \mathrm{~S}$ & 0.44 & 0.44 & 0.5 & 0.42 & 0.42 & 0.41 & 0.42 & 0.41 & 0.8 & 5.2 \\
\hline $\mathrm{NH}_{3}$ & 0.01 & 0.7 & 0.0 & 0.71 & 0.03 & 0.002 & 0.03 & 0.00 & 5.0 & 2364.4 \\
\hline $\cos$ & 0.02 & 0.02 & 0.0 & 0.02 & 0.03 & 0.06 & 0.03 & 0.07 & 5.8 & 77.8 \\
\hline $\mathrm{Ar}$ & 0.04 & 0.05 & 0.0 & 0.04 & 0.05 & 0.04 & 0.06 & 0.05 & 2.0 & 20.6 \\
\hline $\mathrm{HHV}_{\text {w.b. }}\left(\mathrm{MJ} / \mathrm{Nm}^{3}\right)$ & 8.49 & 7.44 & 11.77 & 9.06 & 9.28 & 10.66 & 11.47 & 11.1 & 1.6 & 13.4 \\
\hline
\end{tabular}

* Calculated as the average of the four pairs simulation-reported data described in each entire row.

TABLE 6: Comparison between SNG compositions simulated and reported data under slurry and dry feeding technologies.

\begin{tabular}{|c|c|c|c|c|c|c|c|c|c|}
\hline \multirow{3}{*}{ SNG (\% vol.) } & \multicolumn{4}{|c|}{ Slurry feeding } & \multicolumn{4}{|c|}{ Dry feeding } & \multirow{3}{*}{$\begin{array}{l}\text { RMSD } \\
\text { (units) }\end{array}$} \\
\hline & \multicolumn{2}{|c|}{ Bijao } & \multicolumn{2}{|c|}{ Sanoha } & \multicolumn{2}{|c|}{ Bijao } & \multicolumn{2}{|c|}{ Sanoha } & \\
\hline & {$[51]$} & Model & {$[51]$} & Model & {$[51]$} & Model & {$[51]$} & Model & \\
\hline $\mathrm{H}_{2}$ & 0.33 & 1.17 & 0.32 & 1.07 & 0.31 & 1.11 & 0.31 & 1.22 & 0.8 \\
\hline $\mathrm{CH}_{4}$ & 97.83 & 95.98 & 98.2 & 96.55 & 94.11 & 96.02 & 94.18 & 96.05 & 1.8 \\
\hline $\mathrm{CO}_{2}$ & 0.07 & 0.00 & 0.07 & 0.00 & 0.06 & 0 & 0.06 & 0.00 & 0.1 \\
\hline $\mathrm{N}_{2}$ & 1.55 & 2.68 & 1.23 & 2.25 & 5.3 & 2.69 & 5.19 & 2.54 & 2.0 \\
\hline $\mathrm{Ar}$ & 0.23 & 0.17 & 0.17 & 0.13 & 0.21 & 0.18 & 0.26 & 0.19 & 0.1 \\
\hline
\end{tabular}

these species compared with the reference data is higher than $65 \%$. This can be seen in Table 6, where the RMSD of the traces is higher compared with the concentration produced in the gasification process. However, it is important to highlight the relative small magnitude order for $\mathrm{H}_{2}, \mathrm{Ar}, \mathrm{N}_{2}$, and $\mathrm{CO}_{2}$ concentration levels (lower than $2 \% \mathrm{vol}$ ) against to the $\mathrm{CH}_{4}$ concentration in the SNG (between 94 and $98 \% \mathrm{vol}$ ). Therefore, the traces concentration has a negligible effect on the energy parameters estimated in Section 4.2.

4.2. SNG Production and Quality As Gaseous Fuel. Despite the model low accuracy to predict the traces in the SNG stream, in Table 7, it can be observed that $\mathrm{HHV}_{\mathrm{SNG}}$ calculated by the simulations is almost equal for both Sanoja and Bijao Colombian coals (independent of the feeding technology), and in both cases $\mathrm{HHV}_{\mathrm{SNG}}$ is quite similar to the reported data in the literature. The average relative error of $\mathrm{HHV}_{\mathrm{SNG}}$ is lower than 2\%; this can be explained due to similar $\mathrm{CH}_{4}$ contents (Table 6) obtained from methanation stage. Thereby, feeding technology would not affect $\mathrm{HHV}_{\mathrm{SNG}}$. According to $\mathrm{HHV}_{\mathrm{SNG}}$ and $\mathrm{WI}_{\mathrm{SNG}}$ presented in Table 7, the simulated SNG can be classified as a high quality natural gas (NG) and it can be transported by gas pipe lines (for both coals and both technologies used) [22]. The high quality classification is due to the fact blank that $\mathrm{HHV}_{\mathrm{SNG}}$ and $\mathrm{WI}_{\mathrm{SNG}}$ parameters are between the ranges defined by Colombian regulatory norms. $\mathrm{HHV}_{\mathrm{NG}}$ must be between 35.4 and $42.8 \mathrm{MJ} / \mathrm{m}^{3}$ and WI 47.7-52.7 MJ/m $\mathrm{m}^{3}$ [55]. Therefore, the SNG produced and distributed can be used in transport, power, and heat generation in industrial and domestic systems [21]. Thereby, the SNG can contribute to meet the increasingly high demand of the gaseous fuel in Colombia.

It is evidenced in Table 7 that for both feeding technologies the simulation of SNG production from Colombian coal gasification does not show significant differences (in mass flows or volumetric flows) when compared with reference report [51]. This is due to the coherent RE that varies between $2.7 \%$ and $4.2 \%$. Therefore, the models developed in this work can be considered as computational tools to study the coal to SNG process. The differences between simulated and reference data can be attributed to the unavailability of STEAM flow rates in the reported data (Table 4) and its incidence in global mass balances.

Regarding the power of the SNG (Table 7), the values calculated are between the expected error boundaries due to mass flow and HHV differences among simulations and reported data. The power is overestimated by $9.5 \%$ with both coals without relying on the technology. The higher potential energy obtained for Sanoha coal is due to its better quality as fuel (Table 1).

4.3. Mass and Energy Efficiencies. The carbon conversion efficiency (CCE) is presented in Figure 10. It is observed that 
TABLE 7: Model validation with regard to SNG production and quality as gaseous fuel.

\begin{tabular}{|c|c|c|c|c|c|c|c|c|c|c|}
\hline \multirow{3}{*}{ Energy parameter } & \multicolumn{4}{|c|}{ Slurry feeding } & \multicolumn{4}{|c|}{ Dry feeding } & \multirow{3}{*}{$\begin{array}{l}\text { RMSD } \\
\text { (units) }\end{array}$} & \multirow{3}{*}{$\begin{array}{l}\overline{\mathrm{RE}} \\
(\%)\end{array}$} \\
\hline & \multicolumn{2}{|c|}{ Bijao } & \multicolumn{2}{|c|}{ Sanoha } & \multicolumn{2}{|c|}{ Bijao } & \multicolumn{2}{|c|}{ Sanoha } & & \\
\hline & {$[51]$} & Model & {$[51]$} & Model & {$[51]$} & Model & {$[51]$} & Model & & \\
\hline $\mathrm{HHV}_{\mathrm{SNG}}\left(\mathrm{MJ} / \mathrm{Nm}^{3}\right)$ & 39 & 38.33 & 39.1 & 38.55 & 37.5 & 38.34 & 37.5 & 38.37 & 0.74 & 1.9 \\
\hline Mass flow (kg/h) & 78400 & 81006 & 82700 & 86063 & 79300 & 80504.8 & 82000 & 80332 & 2362.98 & 2.7 \\
\hline $\begin{array}{l}\text { Volumetric flow } \\
\text { (MMFCD) }\end{array}$ & 96.81 & 101.18 & 102.51 & 107.49 & 95.3 & 100.55 & 98.56 & 100.34 & 4.32 & 4.2 \\
\hline $\mathrm{WI}\left(\mathrm{MJ} / \mathrm{m}^{3}\right)$ & 51.6 & 51.68 & 51.9 & 51.98 & 49 & 51.70 & 49 & 51.73 & 1.92 & 2.8 \\
\hline Power (MW) & 1147 & 1250 & 1221 & 1328 & 1107 & 1242 & 1146 & 1239 & 110.6 & 9.5 \\
\hline
\end{tabular}

* Calculated as the average of the four pairs simulation-reported data described in each entire row.

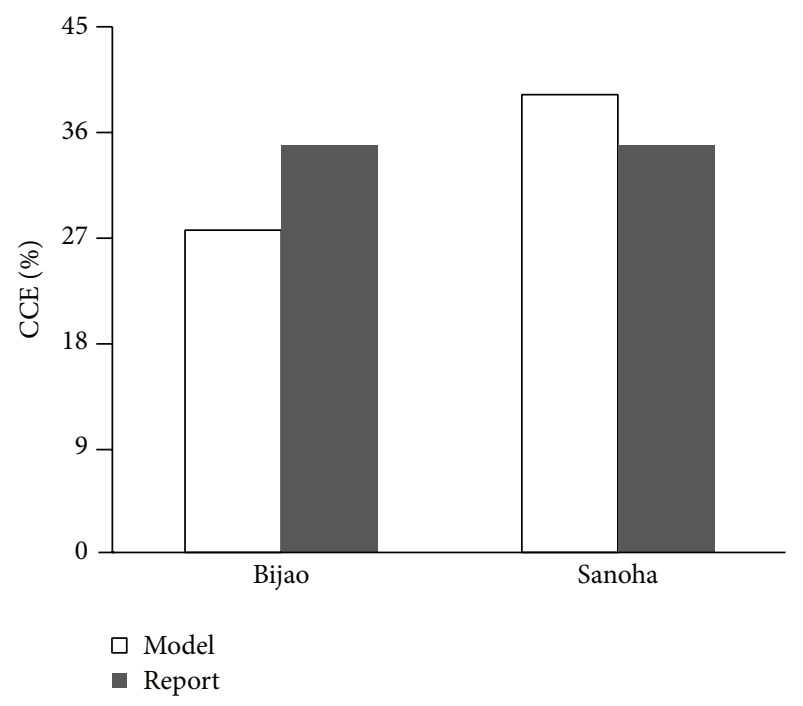

(a)

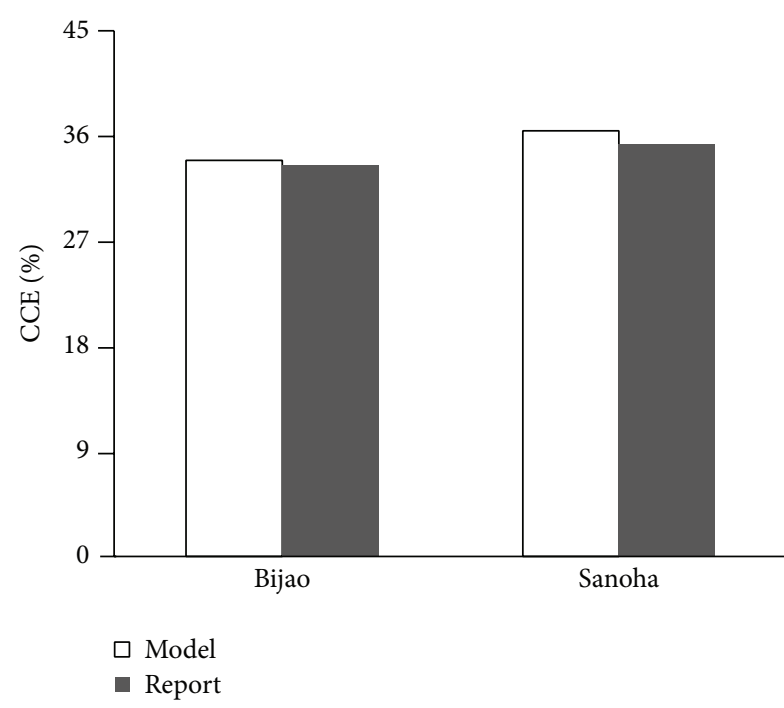

(b)

Figure 10: Carbon conversion efficiency ( $\mathrm{kg} \mathrm{CH}_{4} / \mathrm{kg}$ coal). Comparison for simulated and reported data for two Colombian coals; (a) slurry feeding technology and (b) dry feeding technology.

Sanoha coal tends to give higher coal conversion, especially with the slurry feeding technology. This could be explained by the higher volatile matter contents of this coal (Table 1); and because of the slurry feeding technology, the first one of two gasification stages operates at higher temperatures than the gasifier dry feeding technology (Table 4).

The difference between simulated CCE and technical report data is about $3.5 \%$. Moreover, the simulated data agree with biomass gasification yields reported in the literature, around $26 \% \mathrm{~kg} \mathrm{CH} / \mathrm{kg}$ wood [25]. Differences of CCE around $3 \%-4 \%$ between coal and wood as raw material can be explained by the coal higher fixed carbon with regards to wood or biomass.

It is observed from Figure 11 that cold gas efficiency is slightly higher for dry feeding technology, as expected according to the literature [12]. This trend is due to the slurry feeding technology requiring more energy for the autothermal process to vaporize water in the gasifier. Nevertheless, relative differences between reported and simulated data are almost meaningless, independent of the coal or the simulated technology.
Figure 12 shows that process efficiency is higher for the slurry feeding technology when compared with dry feeding technology, independent of the coal. This is explained because the higher methane content in syngas from slurry technology produces a higher syngas quality to be fed into the catalytic methane reactor. The same trend is observed in the comparison of global efficiencies, Figure 13.

From Figures 10-13, it can be observed that even when efficiencies estimated by the simulations with dry technology are slightly lower than those obtained with slurry feeding technology, the average margin of error between the model and technical report is less than $5 \%$. It is clear that the process efficiency (Figure 12) is 3\% higher for Sanoha coal with regard to Bijao coal. This is due to the Sanoha coal having a higher quality rank than Bijao coal (Table 1).

The process and global efficiencies are higher for slurry feeding technology (Figures 12 and 13). This is due to the higher hydrogen concentration in the syngas produced with the slurry feed technology against dry feed technology [21].

The slurry feeding technology tends to be more efficient than dry feeding technology in the process of coal to SNG 


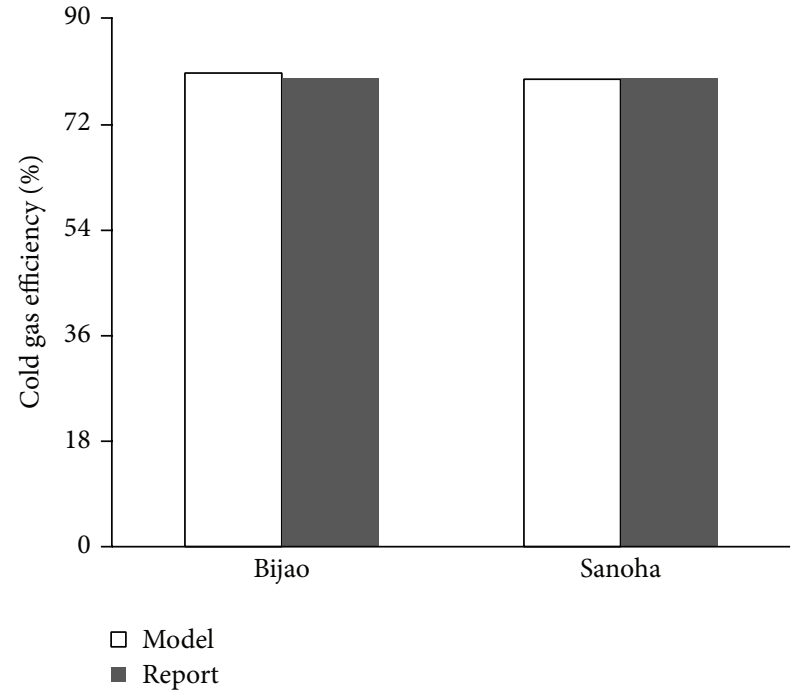

(a)

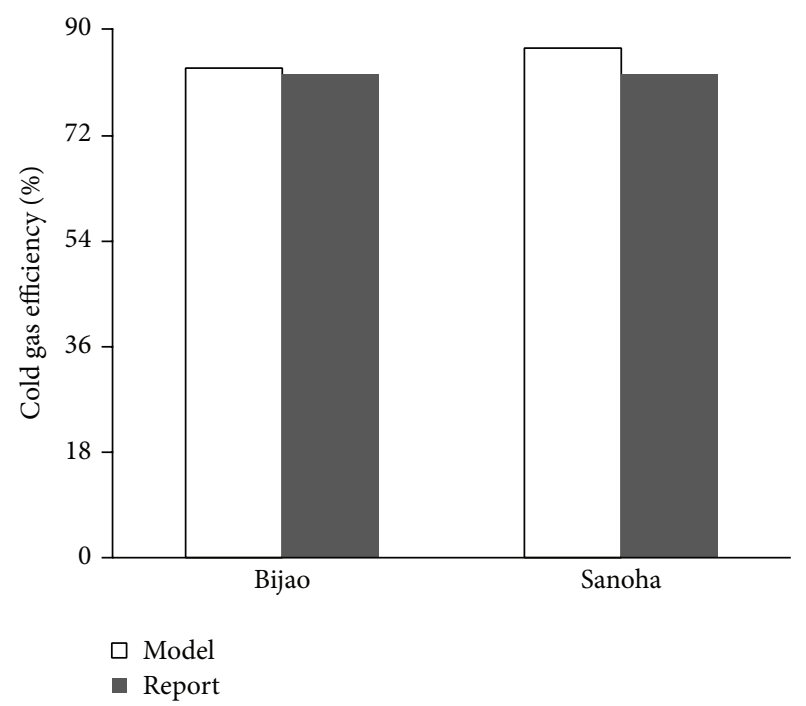

(b)

FIGURE 11: Cold gas efficiency (\%). Comparison between simulated and reported data for two Colombian coals; (a) slurry feeding technology and (b) dry feeding technology.

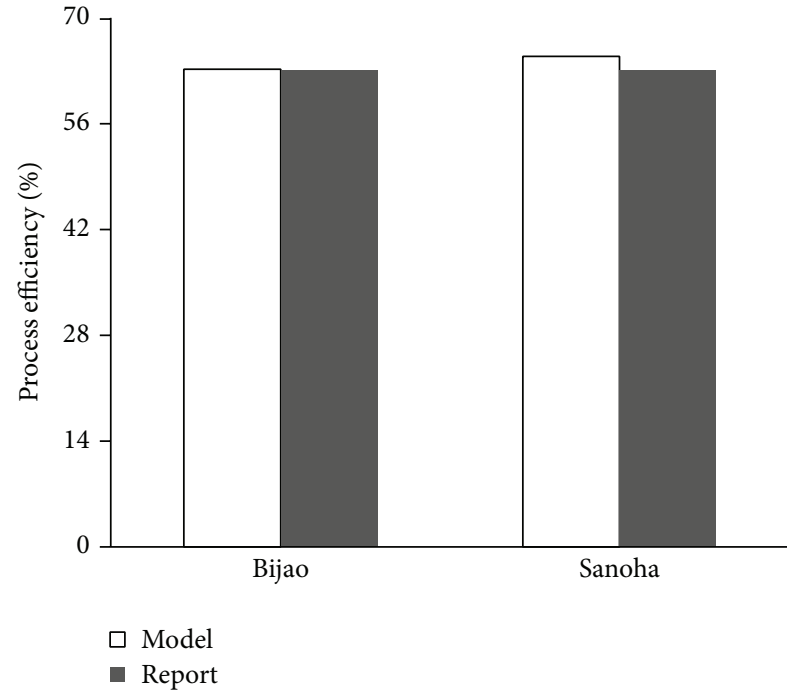

(a)

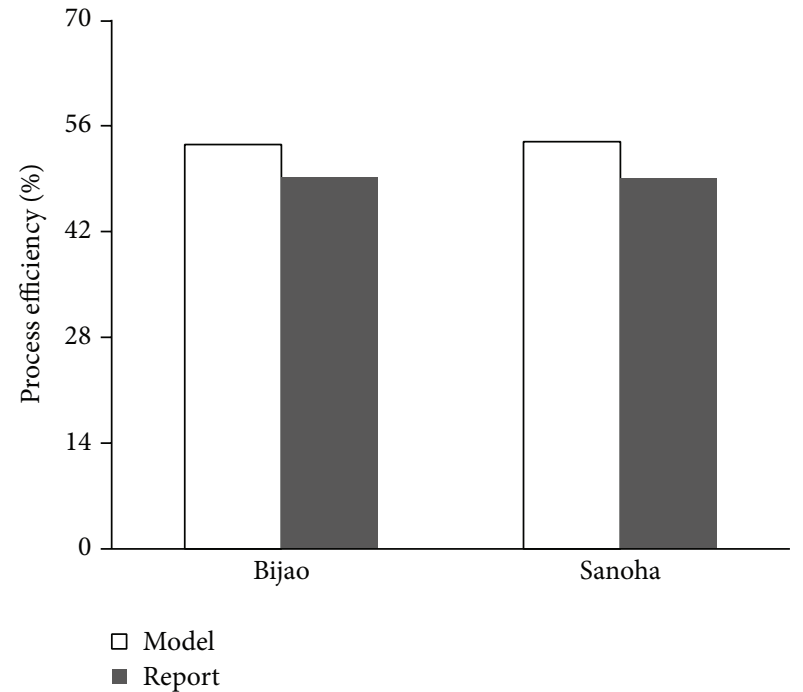

(b)

Figure 12: Process efficiency (\%). Comparison between simulated and reported data for two Colombian coals; (a) slurry feeding technology and (b) dry feeding technology.

simulated in this work. Differences in these parameters were not found in function of the coal rank. The cold gas efficiency is similar to all simulated cases with a slightly improvement for dry feeding technology. The gasification efficiency is better for Sanoha coal due to its fixed carbon content and higher $\mathrm{HHV}_{\text {coal }}$ (Tables 1 and 5).

The RMSD was estimated accounting all data presented. Low differences between simulated and reported data, for both coals using the two different feeding technologies, were found. These values indicate a good agreement between simulated data with the models described in this study and reported data available from the literature. Therefore, the model developed in this paper constitutes a valuable and versatile tool to study the thermodynamic performance of the solid fuels to SNG process via gasification.

\section{Conclusions}

A model to simulate the SNG production via coal gasification process has been developed using Aspen Plus software. The model considers two different typical technologies to supply the fuel into the gasification process. The feeding systems are coal-water slurry and dry coal. The model can simulate different solid fuel types. Therefore, the effect of using two different Colombian coals, Bijao and Sanoha, is considered in this work. 


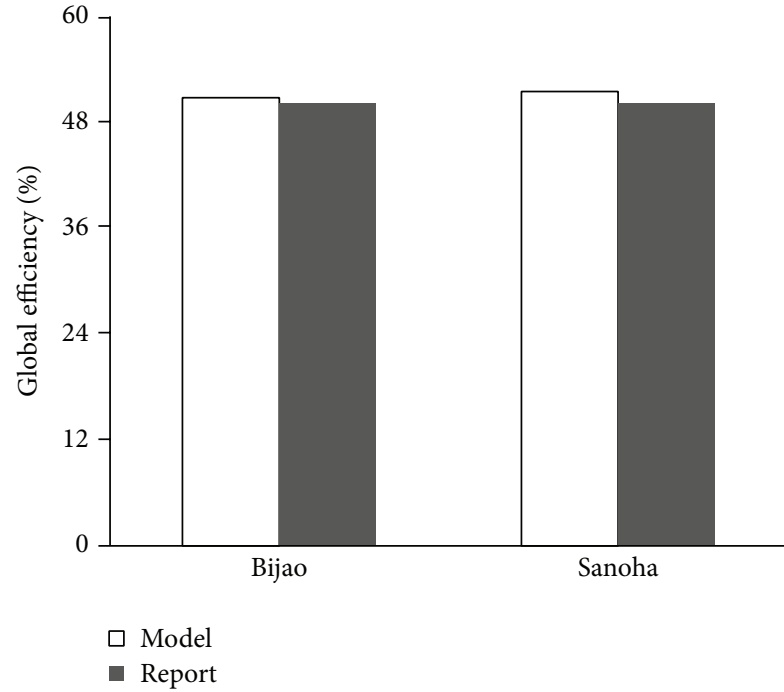

(a)

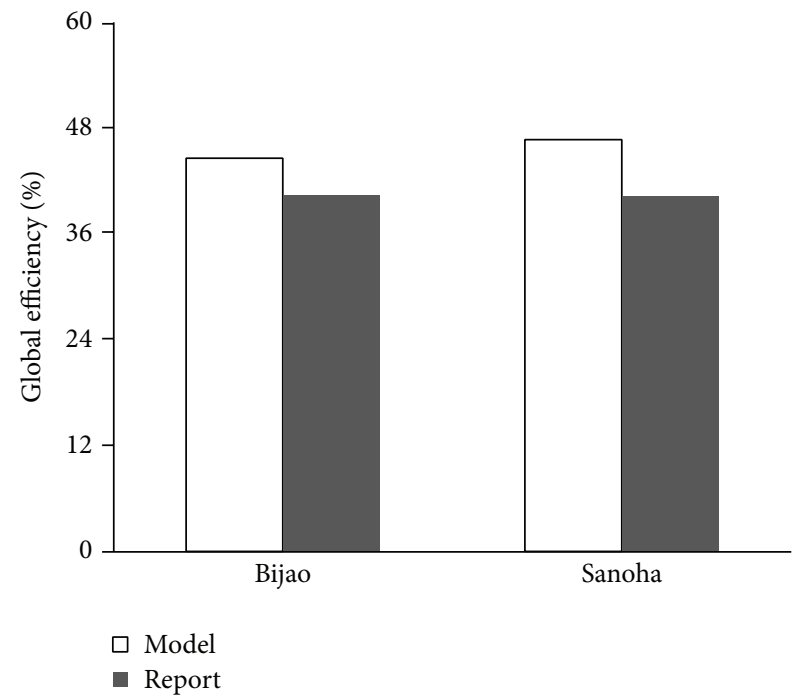

(b)

FIGURE 13: Global efficiency (\%). Comparison between simulated and reported data for two Colombian coals; (a) slurry feeding technology and (b) dry feeding technology.

A global comparison between reported and simulated data presents an average relative error lower than $13 \%$. Therefore, the developed model is able to predict the composition and heating values of syngas and SNG and the SNG quality and energy parameters of the process and the trends. The computational model presented in this work and developed in Aspen Plus v7.3 software can be used for gaining a fundamental understanding of the engineering and optimization of the process, even when scaled up.

According to the simulation process, it was found that coal rank does not significantly affect energy indicators such as cold gas, process, and global efficiencies. However, feeding technology clearly has an effect on these energy parameters. The process and global efficiencies are higher for slurry feeding technology, while cold gas efficiency was higher for dry feeding technology; these results agree with the literature. According to $\mathrm{HHV}_{\mathrm{SNG}}$ and WI, the simulated SNG from both coals and both technologies can be classified as a high quality NG in Colombia. Therefore, the gaseous fuel can be transported by gas pipe lines and the SNG can contribute to meet the increasingly high demand of the gaseous fuel in Colombia.

Since the proposed model can be used to analyze various types of entrained flow reactors with different operating conditions, it can be considered a versatile and useful computational tool to optimize the coal to SNG process. In a future work, a sensitivity analysis of the effect of Colombian coal rank (subbituminous to semi-anthracite) will be conducted.

\section{Nomenclature}

AGR:

CCE:

CGE:

d.b:

Acid gas recovery unit

Coal conversion efficiency (\%)

Cold gas efficiency (\%)

Dry basis
ER: $\quad$ Equivalent ratio (-)

$\mathrm{ER}_{\text {stq }}: \quad$ Stoichiometric equivalence ratio (-)

HHV: $\quad$ Higher heating value $\left(\mathrm{kJ} / \mathrm{Nm}^{3}\right)$

IGCC: Integrated gasification combined cycle plant

$\dot{m}: \quad$ Mass flow $(\mathrm{kg} / \mathrm{s})$

M: $\quad$ Molecular weight $(\mathrm{kg} / \mathrm{kmol})$

MMFCD: Millions of cubic feet per day

$n, m, p, q, r$ : Molecular subindex of recursive fuel substitute formula

P: $\quad$ Thermal power of synthetic natural gas $(\mathrm{kW})$

RE: $\quad$ Relative error

$\overline{\mathrm{RE}}$ : $\quad$ Average relative error

RMSD: $\quad$ Root mean squared deviation (-)

$R / P: \quad$ Reserves-to-production ratio

SNG: $\quad$ Synthetic or substitute natural gas

USW: Urban solid wastes

w.b.: $\quad$ Wet basis

WGSR: Water gas shift reactor

$X_{i}: \quad$ Mass fraction of substance $i(-)$

$Y_{j}: \quad \quad$ Molar fraction of substance $j(-)$

WI: $\quad$ Wobbe Index $\left(\mathrm{MJ} / \mathrm{Nm}^{3}\right)$

$\eta_{\mathrm{cg}}: \quad$ Cold gas efficiency (\%)

$\eta_{\text {global }}: \quad$ Global efficiency (\%)

$\eta_{\text {pro }}: \quad$ Process efficiency $(\%)$

$\varphi: \quad$ Hypothetical stoichiometric coefficient (mol)

Density $\left(\mathrm{kg} / \mathrm{m}^{3}\right)$.

\section{Aspen Plus Model Hierarchy Acronyms}

AGR: $\quad$ Hierarchy for acid gas recovery unit FEEDING: Hierarchy for slurry preparation 
GASIFIC: Hierarchy for gasification stage METHANAT: Hierarchy for methanation stage SHIFTING: Hierarchy for water gas shift reactor.

Aspen Plus Model Built-In Blocks Acronyms

HEATER-1, HEATER-2, and HEATER-3: Heater units MIXER-1, MIXER-2, and MIXER-3: Mixer units REQUIL-1, REQUIL-2: $\quad$ Equilibrium reactor units RGIBB-1, RGIBB-2: Gibbs reactor units RYIELD: $\quad$ Yield reactor unit SPLIT1, SPLIT-2, QSPLIT, SSPLIT, SEP-1, Separation SEP-2, and SEP-3: units or stream divisor units.

Aspen Plus Model Streams Acronyms

ACID-G, ADJ-SYNG, CHAR, CO2, COAL, COND-1, COND-2, H-2, H-3, HEAT-1, OXYGEN, S-1, S-2, S-3, S-4, S-5, S-6, S-7, S-8, S-9, S-10, S-11, S-12, S-13, S-14, S-15, SLAG, SNG, STEAM, SYNGAS, TO-GASIF, TO-METHA, WATER, WATER-RE, WATQFEED.

\section{Conflict of Interests}

The authors declare that there is no conflict of interests regarding the publication of this paper.

\section{Acknowledgment}

The authors would like to thank the energy Colombian company Celsia S.A. ESP for the financial support of the project: developing and validation of a computational model to simulate the production of synthetic natural gas by means of coal gasification with Aspen Plus: effect of the Colombian coals rank (in Spanish)—code: PI12-1-05.

\section{References}

[1] M. Höök and K. Aleklett, "A review on coal-to-liquid fuels and its coal consumption," International Journal of Energy Research, vol. 34, no. 10, pp. 848-864, 2010.

[2] J. Lu, L. Yu, X. Zhang, S. Zhang, and W. Dai, "Hydrogen production from a fluidized-bed coal gasifier with in situ fixation of $\mathrm{CO}_{2}$. Part I. Numerical model," Chemical Engineering and Technology, vol. 31, no. 2, pp. 197-207, 2008.

[3] P. J. Robinson and W. L. Luyben, "Simple dynamic gasifier model that runs in aspen dynamics," Industrial and Engineering Chemistry Research, vol. 47, no. 20, pp. 7784-7792, 2008.

[4] Z. Yuehong, W. Hao, and X. Zhihong, "Conceptual design and simulation study of a co-gasification technology," Energy
Conversion and Management, vol. 47, no. 11-12, pp. 1416-1428, 2006.

[5] NETL Gasifipedia, Coal Power Gasification, 2013, http://www.netl.doe.gov/technologies/coalpower/gasification/ gasifipedia/.

[6] J. Lee, S. Park, H. Seo et al., "Effects of burner type on a bench-scale entrained flow gasifier and conceptual modeling of the system with Aspen Plus," Korean Journal of Chemical Engineering, vol. 29, no. 5, pp. 574-582, 2012.

[7] IEA Clean Coal Centre, Future Development of IGCC, 2008, http://www.iea-coal.org.uk/documents/82119/7089/Future-developments-in-IGCC.

[8] Unidad de Planeación Minero Energética (UPME) and Ministerio de Minas y Energía (Colombia), "Plan de Abastecimiento para el Suministro y Transporte de Gas Natural," 2010, http://www.upme.gov.co/Docs/Plan_Abast_Gas_Natural/ PLAN_ABASTECIMIENTO_GAS\%20NATURAL_2009.pdf.

[9] A. Martínez, "La actualidad del gas natural en Colombia," Revista Petrotecnia, 2010, http://www.petrotecnia.com.ar.

[10] British Petroleum, BP Statistical Review of World Energy, 2011, http://www.bp.com/content/dam/bp-country/de_de/PDFs/brochures/statistical_review_of_world_energy_full_report_2011 .pdf.

[11] M. Gräbner and B. Meyer, "Performance and exergy analysis of the current developments in coal gasification technology," Fuel, vol. 116, pp. 910-920, 2014.

[12] C. Kunze and H. Spliethoff, "Modelling, comparison and operation experiences of entrained flow gasifier," Energy Conversion and Management, vol. 52, no. 5, pp. 2135-2141, 2011.

[13] N. Seifkar, W. Davey, and J. Sarvinis, "Comparison of several coal gasification processes," in Proceedings of the 8th World Congress of Chemical Engineering (WCCE '09), August 2009.

[14] O. Maurstad, H. Herzog, O. Bolland, and J. Beér, "Impact of coal quality and gasifier technology on IGCC performance," Norwegian Research Council in the KLIMATEK program, 2013, http://sequestration.mit.edu/pdf/GHGT8_Maurstad.pdf.

[15] G. W. Yu, Y. M. Wang, and Y. Y. Xu, "Modeling analysis of shell, Texaco gasification technology's effects on water gas shift for Fischer-Tropsch process," Advanced Materials Research, vol. 608-609, pp. 1446-1453, 2012.

[16] M. Prins, R. van den Berg, E. van Holthoon, E. van Dorst, and F. Geuzebroek, "Technological developments in IGCC for carbon capture," Chemical Engineering and Technology, vol. 35, no. 3, pp. 413-419, 2012.

[17] M. J. Bockelie, M. K. Denison, Z. Chen, C. L. Senior, and A. F. Sarofim, "Using Models to Select Operating Conditions for Gasifiers," Reaction Engineering International, http://energy.reaction-eng.com/downloads/REI_ processmodel.pdf.

[18] S. Armin, Simulation of Coal Gasification Process Inside a Two-Stage Gasifier, Department of Mechanical Engineering, University of New Orleans, New Orleans, La, USA, 2004.

[19] A. Silaen and T. Wang, "Investigation of the coal gasification process under various operating conditions inside a twostage entrained flow gasifier," Journal of Thermal Science and Engineering Applications, vol. 4, no. 2, Article ID 021006, 2012.

[20] C. R. Vitasari, M. Jurascik, and K. J. Ptasinski, "Exergy analysis of biomass-to-synthetic natural gas (SNG) process via indirect gasification of various biomass feedstock," Energy, vol. 36, no. 6, pp. 3825-3837, 2011. 
[21] A. Tremel, M. Gaderer, and H. Spliethoff, "Small-scale production of synthetic natural gas by allothermal biomass gasification," International Journal of Energy Research, vol. 37, no. 11, pp. 1318-1330, 2013.

[22] S. Heyne, H. Thunman, and S. Harvey, "Extending existing combined heat and power plants for synthetic natural gas production," International Journal of Energy Research, vol. 36, no. 5, pp. 670-681, 2012.

[23] B. James, Cost and Performance Baseline for Fossil Energy Plants, vol. 1 of Bituminous Coal and Natural Gas to Electricity, DOE-National Energy Technology Laboratory, 2010, http:// www.netl.doe.gov/research/energy-analysis/energy-baselinestudies.

[24] F. Trippe, M. Fröhling, F. Schultmann, R. Stahl, and E. Henrich, "Techno-economic assessment of gasification as a process step within biomass-to-liquid (BtL) fuel and chemicals production," Fuel Processing Technology, vol. 92, no. 11, pp. 2169-2184, 2011.

[25] K. J. Ptasinski, A. Sues, and M. Jurascik, "Biowates to biofuels: routes via gasification," in Biomass Gasification: Chemistry, Processes and Applications, J. P. Badea and A. Levi, Eds., pp. 86197, Nova Science, New York, NY, USA, 2009.

[26] O. Maurstad, "An overview of coal based integrated gasification combined cycle (IGCC) technology," Publication No. LFEE 2005-002 WP, Massachusetts Institute of Technology, 2005, http://sequestration.mit.edu/pdf/LFEE_2005-002_WP.pdf.

[27] Aspen Tech Web Site, http://www.aspentech.com/products/ aspen-plus.aspx.

[28] P. L. Douglas and B. E. Young, "Modelling and simulation of an AFBC steam heating plant using ASPEN/SP," Fuel, vol. 70, no. 2, pp. 145-154, 1991.

[29] C. E. Backham and P. L. Douglas, "Simulation of a coal hydrogasification process with integrated $\mathrm{CO} 2$ capture," Combust Canada, 3A, 2003.

[30] W. Doherty, A. Reynolds, and D. Kennedy, "The effect of air preheating in a biomass CFB gasifier using ASPEN Plus simulation," Biomass and Bioenergy, vol. 33, no. 9, pp. 1158-1167, 2009.

[31] R. Nayak and R. Mewada, "Simulation of coal gasification process using ASPEN PLUS," in Proceedings of the International Conference On Current Trends In Technology: Nuicone, New Delhi, India, 2011.

[32] W. Doherty, A. Reynolds, and D. Kennedy, "Simulation of a circulating fluidised bed biomass gasifier using ASPEN plus-a performance analysis," in Proceedings of the 21st International Conference on Efficiency, Cost, Optimization, Simulation and Environmental Impact of Energy Systems (ECOS '08), Kraków, Poland, 2008.

[33] A. Ong'iro, V. Ismet Ugursal, A. M. Al Taweel, and G. Lajeunesse, "Thermodynamic simulation and evaluation of a steam CHP plant using ASPEN plus," Applied Thermal Engineering, vol. 16, no. 3, pp. 263-271, 1996.

[34] M. Gazzani, G. Manzolini, E. MacChi, and A. F. Ghoniem, "Reduced order modeling of the Shell-Prenflo entrained flow gasifier," Fuel, vol. 104, pp. 822-837, 2013.

[35] S. Karellas, K. D. Panopoulos, G. Panousis, A. Rigas, J. Karl, and E. Kakaras, "An evaluation of Substitute natural gas production from different coal gasification processes based on modeling," Energy, vol. 45, no. 1, pp. 183-194, 2012.

[36] Q. Yi, J. Feng, and W. Y. Li, "Optimization and efficiency analysis of polygeneration system with coke-oven gas and coal gasified gas by Aspen Plus," Fuel, vol. 96, pp. 131-140, 2012.
[37] A. O. Ong'iro, V. I. Ugursal, A. M. Al Taweel, and D. K. Blamire, "Simulation of combined cycle power plants using the ASPEN PLUS shell," Heat Recovery Systems and CHP, vol. 15, no. 2, pp. 105-113, 1995.

[38] S. Cimini, M. Prisciandaro, and D. Barba, "Simulation of a waste incineration process with flue-gas cleaning and heat recovery sections using Aspen Plus," Waste Management, vol. 25, no. 2, pp. 171-175, 2005.

[39] S. Chern, L. T. Fan, and W. P. Walawender, "Analytical calculation of equilibrium gas composition in a C-H-O-inert system," AIChE Journal, vol. 35, no. 4, pp. 673-675, 1989.

[40] K. G. Mansaray, A. E. Ghaly, A. M. Al-Taweel, F. Hamdullahpur, and V. I. Ugursal, "Mathematical modeling of a fluidized bed rice husk gasifier: part I-model development," Energy Sources, vol. 22, no. 1, pp. 83-98, 2000.

[41] J. Sadhukhan, K. S. Ng, N. Shah, and H. J. Simons, "Heat integration strategy for economic production of combined heat and power from biomass waste," Energy and Fuels, vol. 23, no. 10, pp. 5106-5120, 2009.

[42] L. Shen, Y. Gao, and J. Xiao, "Simulation of hydrogen production from biomass gasification in interconnected fluidized beds," Biomass \& Bioenergy, vol. 32, no. 2, pp. 120-127, 2008.

[43] P. Ji, W. Feng, and B. Chen, "Production of ultrapure hydrogen from biomass gasification with air," Chemical Engineering Science, vol. 64, no. 3, pp. 582-592, 2009.

[44] J. Sadhukhan, Y. Zhao, M. Leach, N. P. Brandon, and N. Shah, "Energy Integration and analysis of solid oxide fuel cell based microcombined heat and power systems and other renewable systems using biomass waste derived syngas," Industrial and Engineering Chemistry Research, vol. 49, no. 22, pp. 11506-11516, 2010.

[45] F. Emun, M. Gadalla, T. Majozi, and D. Boer, "Integrated gasification combined cycle (IGCC) process simulation and optimization," Computers and Chemical Engineering, vol. 34, no. 3, pp. 331-338, 2010.

[46] C. Kunze and H. Spliethoff, "Modelling of an IGCC plant with carbon capture for 2020," Fuel Processing Technology, vol. 91, no. 8, pp. 934-941, 2010.

[47] N. Ramzan, A. Ashraf, S. Naveed, and A. Malik, "Simulation of hybrid biomass gasification using Aspen plus: a comparative performance analysis for food, municipal solid and poultry waste," Biomass and Bioenergy, vol. 35, no. 9, pp. 3962-3969, 2011.

[48] P. Se-Ik, L. Joon-Won, and S. Hea-Kyung, "Effects of different coal type on gasification characteristics," Transactions of the Korean Hydrogen and New Energy Society, vol. 21, pp. 470-477, 2010.

[49] S. Park, J. Lee, H. Seo, G. Kim, and K. Kim, "Experimental investigations of the effect of coal type and coal burner with different oxygen supply angles on gasification characteristics," Fuel Processing Technology, vol. 92, no. 7, pp. 1374-1379, 2011.

[50] L. Waldheim and T. Nilsson, "Heating value of gases from biomass gasification," Report Prepared for IEA Bioenergy Agreement Subcommittee on Thermal Gasification of Biomass, Task 20-Thermal Gasification of Biomass, 2001.

[51] "Coal to SNG Feasibility Study. For the energy Colombian Company Celsia S.A. ESP," Tech. Rep. 60T03800, Jacobs Engineering Group, 2013.

[52] X. Hao, G. Dong, Y. Yang, Y. Xu, and Y. Li, "Coal to Liquid (CTL): commercialization prospects in China," Chemical Engineering \& Technology, vol. 30, no. 9, pp. 1157-1165, 2007. 
[53] S. Jarungthammachote and A. Dutta, "Thermodynamic equilibrium model and second law analysis of a downdraft waste gasifier," Energy, vol. 32, no. 9, pp. 1660-1669, 2007.

[54] M. Vaezi, M. Passandideh-Fard, M. Moghiman, and M. Charmchi, "On a methodology for selecting biomass materials for gasification purposes," Fuel Processing Technology, vol. 98, pp. 74-81, 2012.

[55] CREG, Comisión Reguladora de Energía y Gas de Colombia, Resolución 071, Ministerio de Minas y Energía, 1999, http:// www.creg.gov.co/html/i_portals/index.php. 

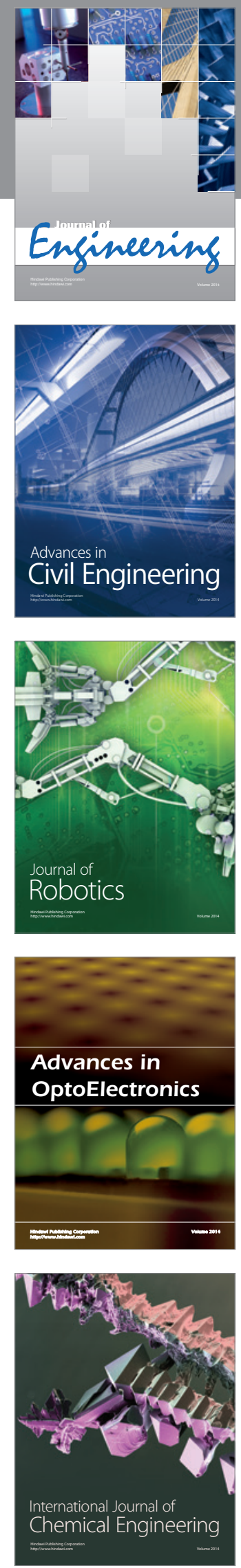

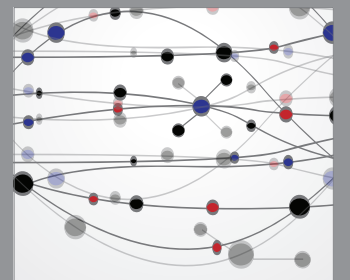

The Scientific World Journal
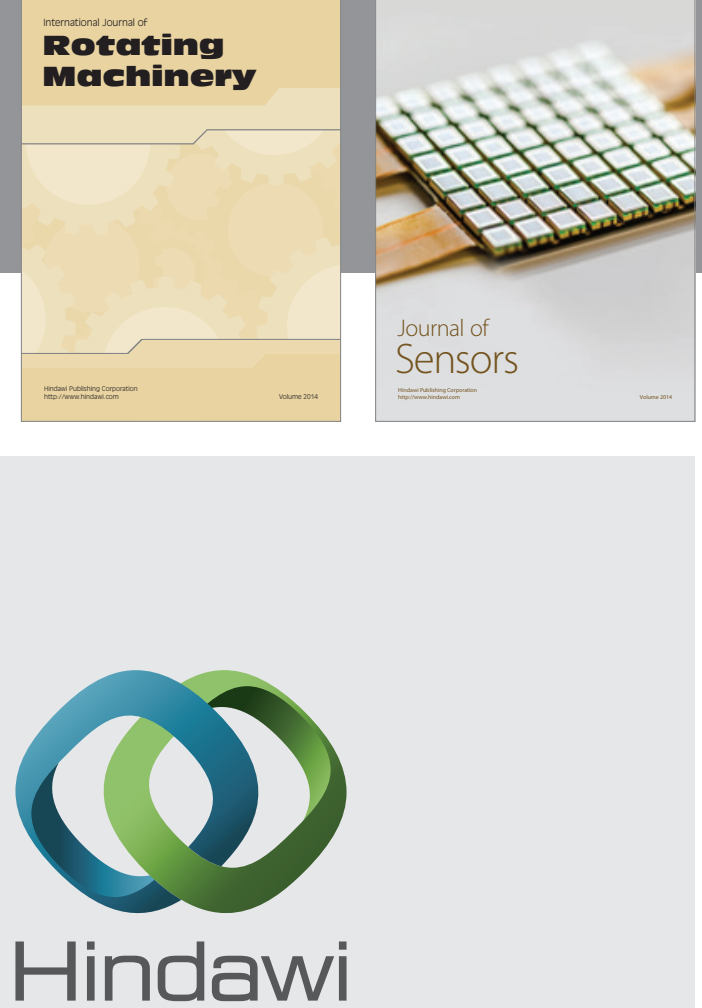

Submit your manuscripts at http://www.hindawi.com
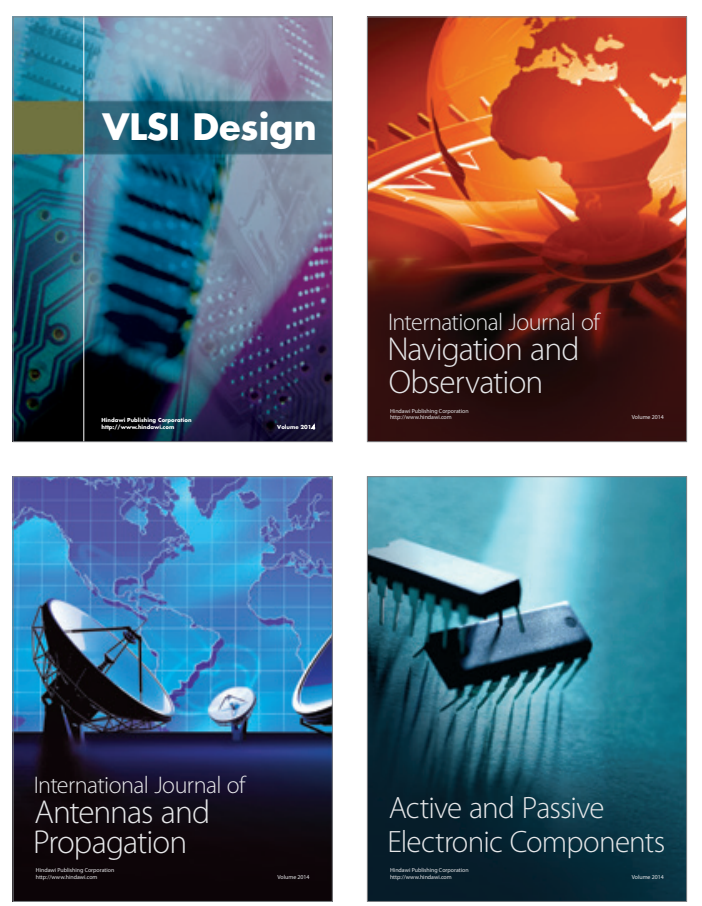
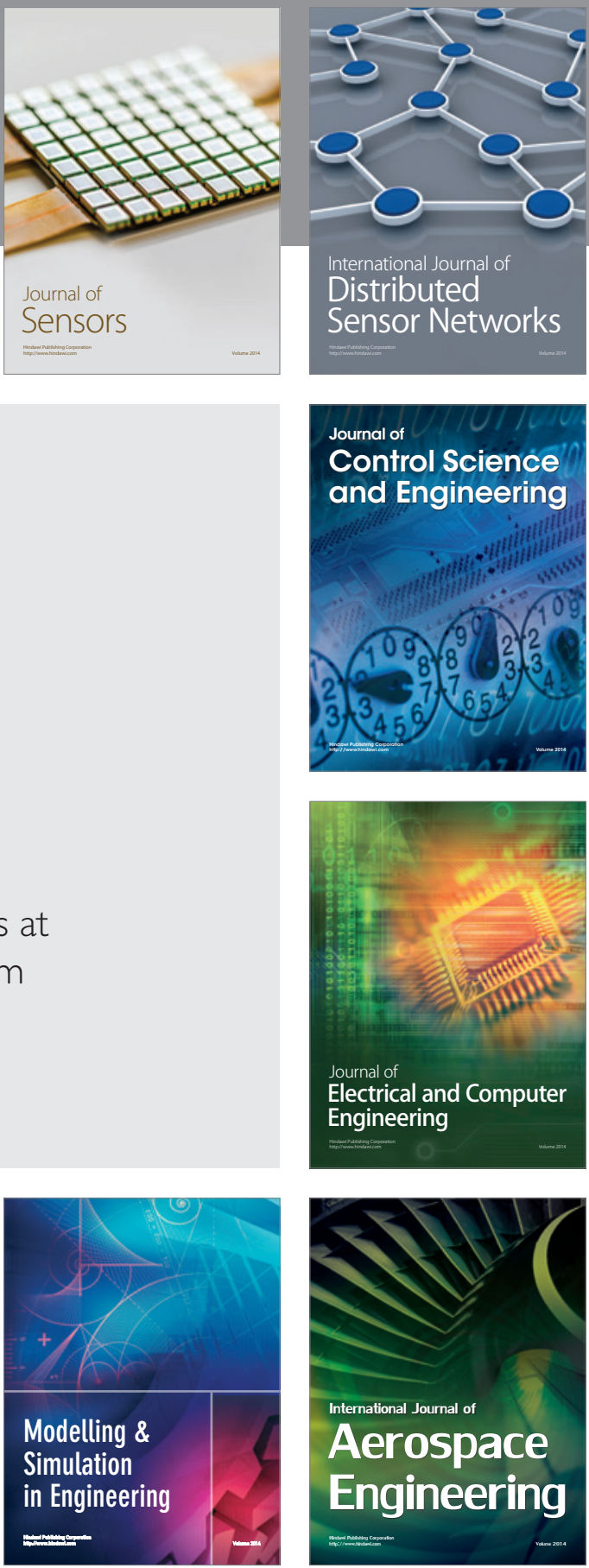

Journal of

Control Science

and Engineering
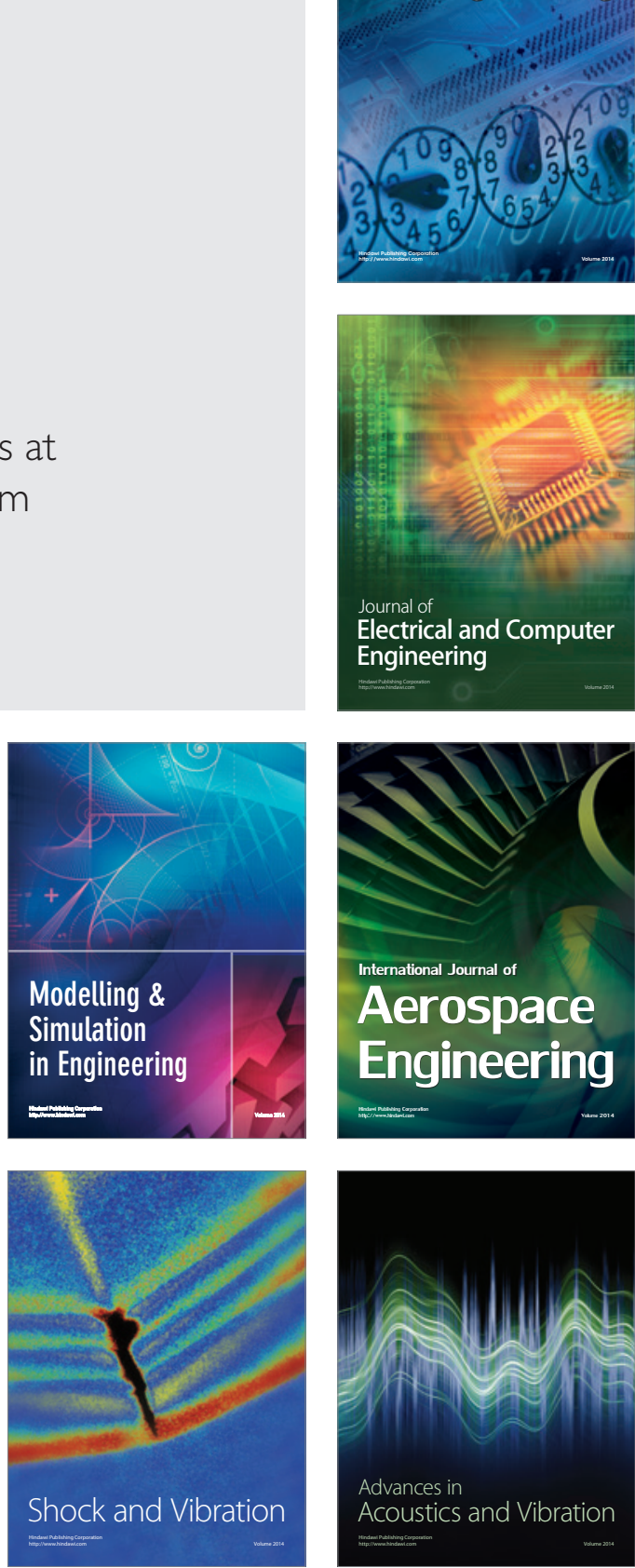